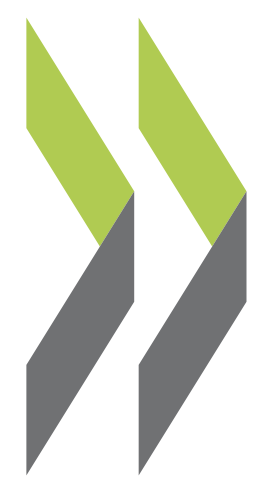

Thailand's education system and skills imbalances: Assessment and policy recommendations

Marieke Vandeweyer, Ricardo Espinoza, Laura Reznikova, Miso Lee, Thanit Herabat 


\section{ECONOMICS DEPARTMENT}

Cancels \& replaces the same document of 8 April 2021

\section{THAILAND'S EDUCATION SYSTEM AND SKILLS IMBALANCES: ASSESSMENT AND} POLICY RECOMMENDATIONS

\section{ECONOMICS DEPARTMENT WORKING PAPERS No. 1641}

By Marieke Vandeweyer, Ricardo Espinoza, Laura Reznikova, Miso Lee and Thanit Herabat

OECD Working Papers should not be reported as representing the official views of the OECD or of its member countries. The opinions expressed and arguments employed are those of the author(s).

Authorised for publication by Alvaro Pereira, Director, Country Studies Branch, Economics Department.

All Economics Department Working Papers are available at www.oecd.org/eco/workingpapers.

JT03474868 
OECD Working Papers should not be reported as representing the official views of the OECD or of its member countries. The opinions expressed and arguments employed are those of the author(s).

Working Papers describe preliminary results or research in progress by the author(s) and are published to stimulate discussion on a broad range of issues on which the OECD works.

Comments on Working Papers are welcomed, and may be sent to OECD Economics Department, 2 rue André Pascal, 75775 Paris Cedex 16, France, or by e-mail to eco.contact@oecd.org.

All Economics Department Working Papers are available at www.oecd.org/eco/workingpapers.

This Working Paper cancels and replaces an earlier version available on 18 December 2020. Updates are provided to references on the following pages:

Page 33:

The research in Reference 55 was carried out by the Bank of Thailand, not by the Office of National Higher Education Science Research and Innovation Policy Council.

These findings are in line with the analysis carried out by the Bank of Thailand (เสาวณี จันทะพงษ์ and นางสาวกานต์ชนิต เลิศเพียรธรรม (Chantapong, Saovanee and Kanchanit Lertpienthum), 2018[55]), which shows that the demand in the Thai labour market is strongest for workers with lower vocational certificates and those with a secondary education or lower level degree, while the supply is highest for individuals with a Page 49: tertiary education degree.

The information of Reference 55, including the issuer, has been clarified.

เสาวณี จันทะพงษ์ and นางสาวกานต์ชนิต เลิศเพียรธรรม (Chantapong, Saovanee and Kanchanit Lertpienthum) (2018), "กับดัก Skills Mismatch และความท้าทายสู Education 4.0", MPG Economic Review, Bank of Thailand (in Thai).

This document and any map included herein are without prejudice to the status of or sovereignty over any territory, to the delimitation of international frontiers and boundaries and to the name of any territory, city or area.

The statistical data for Israel are supplied by and under the responsibility of the relevant Israeli authorities. The use of such data by the OECD is without prejudice to the status of the Golan Heights, East Jerusalem and Israeli settlements in the West Bank under the terms of international law.

\section{(C) OECD (2021)}

You can copy, download or print OECD content for your own use, and you can include excerpts from OECD publications, databases and multimedia products in your own documents, presentations, blogs, websites and teaching materials, provided that suitable acknowledgment of OECD as source and copyright owner is given. Requests for commercial use and translation rights should be submitted to PubRights@oecd.org 


\section{Abstract / Resumé \\ Thailand's education system and skills imbalances: assessment and policy recommendations}

In light of population ageing, globalisation, automation, and the effects of the COVID-19 pandemic, Thailand's labour market is being significantly reshaped, and so are the skills required for higher employability. This paper analyses the capacity of Thailand's education and training system to develop relevant skills from the pre-primary to higher education level, and explores the current state of skills imbalances in the country. It identifies accessibility of schooling, provision of relevant teacher training, and sustained competitiveness of higher education institutions as key areas for improvement. It also points to large skills shortages in the education, and health and social work sectors, and prevalent qualification and field-of-study mismatches. The findings highlight that a responsive education system, together with highquality life-long learning opportunities that are accessible to all and aligned with skill needs, will be essential to equip Thai people with the right skills for navigating the rapidly changing world.

This Working Paper relates to the 2020 OECD Economic Assessment of Thailand (http://www.oecd.org/economy/thailand-economic-snapshot/).

JEL classification: A20, 121, I23, I24, 126, J21, J23, J24, J31, F66

Keywords: Thailand, Education quality, Accessible schooling, Education expansion, STEM skills, Skills imbalances, Lifelong learning, Adult education

\section{Le système d'enseignement et les déséquilibres de compétences en Thaïlande : évaluation et recommandations}

Compte tenu du vieillissement démographique, de la mondialisation, de l'automatisation et des effets de la pandémie de COVID-19, le marché du travail de la Thaïlande est en train de changer considérablement, de même que les compétences requises pour renforcer l'employabilité des individus. Nous analysons dans ce document la capacité du système d'enseignement et de formation de la Thaïlande à doter la population des compétences requises, de l'éducation préprimaire à l'enseignement supérieur, et étudions les problèmes de déséquilibre des compétences qui se posent aujourd'hui dans le pays. Améliorer l'accessibilité de l'enseignement scolaire, assurer une formation adaptée des enseignants et renforcer durablement la compétitivité des établissements d'enseignement supérieur apparaissent comme des axes d'amélioration essentiels. Nous mettons également en évidence d'amples pénuries de compétences dans le secteur de l'éducation ainsi que dans celui de la santé et de l'action sociale, et des problèmes généralisés d'inadéquation des qualifications et du domaine d'études. Les conclusions de nos travaux soulignent qu'un système d'enseignement réactif, conjugué à des mécanismes de formation tout au long de la vie de qualité qui soient accessibles à tous et en phase avec les besoins de compétences, sera essentiel pour doter les Thaillandais des compétences nécessaires pour s'adapter à un monde qui évolue rapidement.

Ce document de travail est lié à l'Évaluation économique de l'OCDE de 2020 consacrée à la Thaïlande (http://www.oecd.org/fr/economie/thailande-en-un-coup-d-oeil/).

Classification JEL : A20, I21, I23, I24, I26, J21, J23, J24, J31, F66

Mots clés : Thaïlande, qualité de l'éducation, accessibilité de l'enseignement scolaire, développement de l'enseignement, compétences en sciences, technologie, ingénierie et mathématiques (STIM), déséquilibres de compétences, formation tout au long de la vie, formation des adultes. 


\section{Table of contents}

\section{Thailand's education system and skills imbalances: assessment and policy} recommendations

The importance of human capital development

The future of work and skills: What are the key challenges for Thailand?

Technology is shifting skills demand

Population ageing is impacting skills supply and demand

Globalisation changes the structure of the labour market $\quad 11$

Skills development as the driver of Thailand $4.0 \quad 12$

Access to education has been on the rise, but challenges remain $\quad 12$

Reducing regional disparities and improving education quality 16

Supporting HEls innovation and alignment of students' educational choices with labour market needs

The ageing of tertiary educated workers has been slowed due to the influx of new graduates, especially in STEM fields

Further stimulating the demand for higher-level skills to achieve full potential of Thailand 4.0

$\begin{array}{ll}\text { The state of skills imbalances in Thailand } & 31\end{array}$

Reducing skills imbalances by promoting adult learning $\quad 36$

$\begin{array}{ll}\text { Promoting participation in adult learning } & 36\end{array}$

Strengthening adult learning investment and incentives toward in-demand skills 41

Assisting workers in sectors undergoing structural change $\quad 42$

References $\quad 45$

\section{Figures}

Figure 1. The supply of industrial robots is on the rise $\quad 7$

Figure 2. Robot use in Thailand is concentrated in a few sectors 8

Figure 3. Jobs with high probability of automation 9

Figure 4. Thailand is one of the most rapidly ageing countries 10

Figure 5. International trade keeps rising 12

Figure 6. Thailand's participation in formal education is around the regional average 15

Figure 7. Thailand's expenditure on primary education is the highest in the region 16

Figure 8. PISA scores are lower than the OECD average, with a growing gap in reading 17

Figure 9. Thailand has a high share of low achievers and a low share of high performers in reading 18

Figure 10. Higher education enrolment has increased until recently 22

Figure 11. Wage premiums of university degrees are strong 24

Figure 12. Educated workforce is becoming older, except for workers with tertiary education 25

Figure 13. The supply of high-skilled workers in different STEM fields is increasing rapidly 26

Figure 14. Young Thais workers predominantly hold degrees in business and administration $\quad 27$

Figure 15. Several occupations and industries are facing substantial shortages 32

Figure 16. Many workers are employed in occupation that do not match their education 34

Figure 17. Relatively few firms train workers in Thailand 37

Figure 18. Adults face multiple barriers to participating in training 38 


\section{Boxes}

Box 1. International examples of second-chance learning options for early school leavers 13

Box 2. Thailand's education policy response to COVID-19 14

Box 3. How are OECD countries dealing with school closures during the pandemic? 19

Box 4. What matters during expansion of pre-primary education - Evidence from a randomised controlled trial in Colombia

Box 5. Thailand's Equitable Education Fund

Box 6. The "Open and Sharing Campus" university model in Korea 23

Box 7. Thailand's initiatives supporting skills development in STEM/STI fields 28

Box 8. Germany's Alliance for Initial and Further Training 30

Box 9. The OECD Skills for Jobs Indicators $\quad 35$

Box 10. Individual Learning Account $\quad 39$ 


\title{
Thailand's education system and skills imbalances: assessment and policy recommendations
}

\author{
By Marieke Vandeweyer, Ricardo Espinoza, Laura Reznikova, Miso Lee and Thanit Herabat ${ }^{1}$
}

\section{The importance of human capital development}

1. Human capital can be broadly defined as the stock of knowledge, skills and other personal characteristics embodied in people that helps them to be productive. Pursuing formal education (early childhood, formal school system, adult training programmes) but also non-formal training, informal learning and work experience all represent investment in human capital (Botev et al., 2019 $\left.{ }_{[1]}\right)$. Broader definitions of human capital also include health (Flabbi and Gatti, 2018[2]; Bloom and Canning, 2003 ${ }_{[3]}$ ).

2. Higher levels of education and skills have been identified as key drivers of productivity growth, allowing people to execute more difficult tasks and to solve more complex problems (Rincon Aznar et al., $\left.2015_{[4]}\right)$. Differences in returns to education have proven effective in explaining productivity across OECD countries and over time (Botev et al., 2019 $9_{[1]}$ ). Human capital complements other types of capital, such as technology. For example, technology adoption will have very little practical effect on economic growth processes unless it is disseminated by education which creates the simple basic capacities to utilise the technology and learn on the job (Mcmahon, 2000[5]).

3. However, the impact of human capital development goes beyond a direct effect on productivity and economic growth. Investment in human capital also has an impact on health outcomes, including greater longevity and reduced infant mortality; increasing democratisation, human rights, and political stability; poverty reduction and reduction of inequality; environmental sustainability; and reducing homicide and property crime rates (Mcmahon, $2000_{[5]}$ ). These, in turn, all have indirect effects on economic growth.

\footnotetext{
${ }^{1}$ Marieke Vandeweyer is a Senior Policy Analyst at the OECD Centre for Skills. Ricardo Espinoza and Laura Reznikova are Analysts at the OECD Centre for Skills. Miso Lee is an Analyst at the OECD Directorate for Employment, Labour and Social Affairs. Thanit Herabat is member of the Office of the National Economic and Social Development Council, Thailand. The authors would like to thank Thai officials, members of the OECD Economic and Development Review Committee, Alvaro Pereira, Isabell Koske, Patrick Lenain (OECD Economics Department), Andrew Bell, Michele Cimino, Andrea Cornejo (OECD Centre for Skills), Alessandro Goglio (OECD Directorate for Employment, Labour and Social Affairs), and Haruki Seitani (formerly at the OECD Economics Department) for useful comments and suggestions. The paper has also benefited from valuable contributions from Manasit Choomsai Na Ayudhaya (the Office of the National Economic and Social Development Council, Thailand). Special thanks go to Isabelle Luong for statistical assistance, and Stephanie Henry for editorial coordination (OECD Economics Department).
} 


\section{The future of work and skills: What are the key challenges for Thailand?}

\section{Technology is shifting skills demand}

4. While technological advances help workers to improve their productivity and create new tasks or jobs opportunities, they are also automating an increasing number of tasks traditionally performed by humans. Initially, automation focused primarily on routine tasks (e.g. clerical work, bookkeeping, basic paralegal work and reporting), but with the advent of Big Data, artificial intelligence (AI), the Internet of Things (IoT) and ever-increasing computing power (i.e. the digital revolution), non-routine tasks are increasingly likely to become automated. (OECD, 2019[6])

5. The diffusion of industrial robots perhaps best epitomises technological penetration and the possibility of job automation in the workplace. Robots have been used for decades, but their diffusion has recently accelerated thanks to the advanced robotics technologies and development of high-tech or smart robots. They now spread beyond the manufacturing sector and manual tasks. For example, supermarkets have started to employ robots as shop assistants, and Amazon and others retailers are piloting cashierless stores. Data from the International Federation of Robotics shows that orders of industrial robots increased threefold globally between 2003 and 2015, and the trend is projected to accelerate further (Figure 1, Panel A). The penetration of industrial robots is not limited to advanced economies. The data also shows that many emerging countries, including Thailand, closely follow international trends of automation. The annual supply of industrial robots in Thailand was estimated to be around 900 in the 2000s, but it jumped to 3000 in the last decade (Figure 1, Panel B).

Figure 1. The supply of industrial robots is on the rise
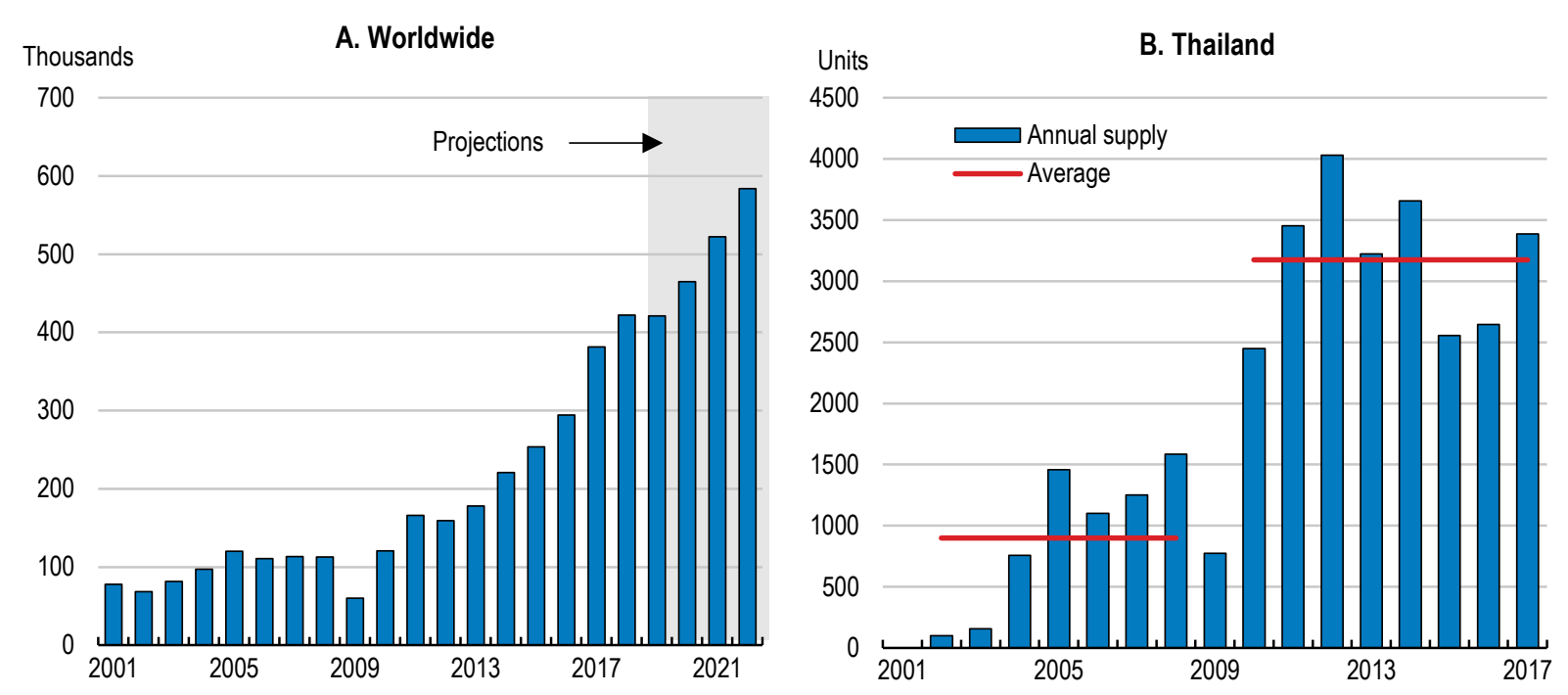

Source: International Federation of Robotics (IFR).

6. The intensity of robot use varies considerably across industries. Moreover, countries differ substantially in terms of the industries that use robotics most intensively (Figure 2). International comparison shows that Thailand stands out for its very high concentration of robots in the automotive sector as well as in the manufacturing of plastic and chemical products, where opportunities for using robots in larger scale assembly productions have also increased recently. In 2017 , more than $85 \%$ of industrial robots were used in the automotive and plastic/chemical products sectors. 


\section{Figure 2. Robot use in Thailand is concentrated in a few sectors}

\section{7 data}

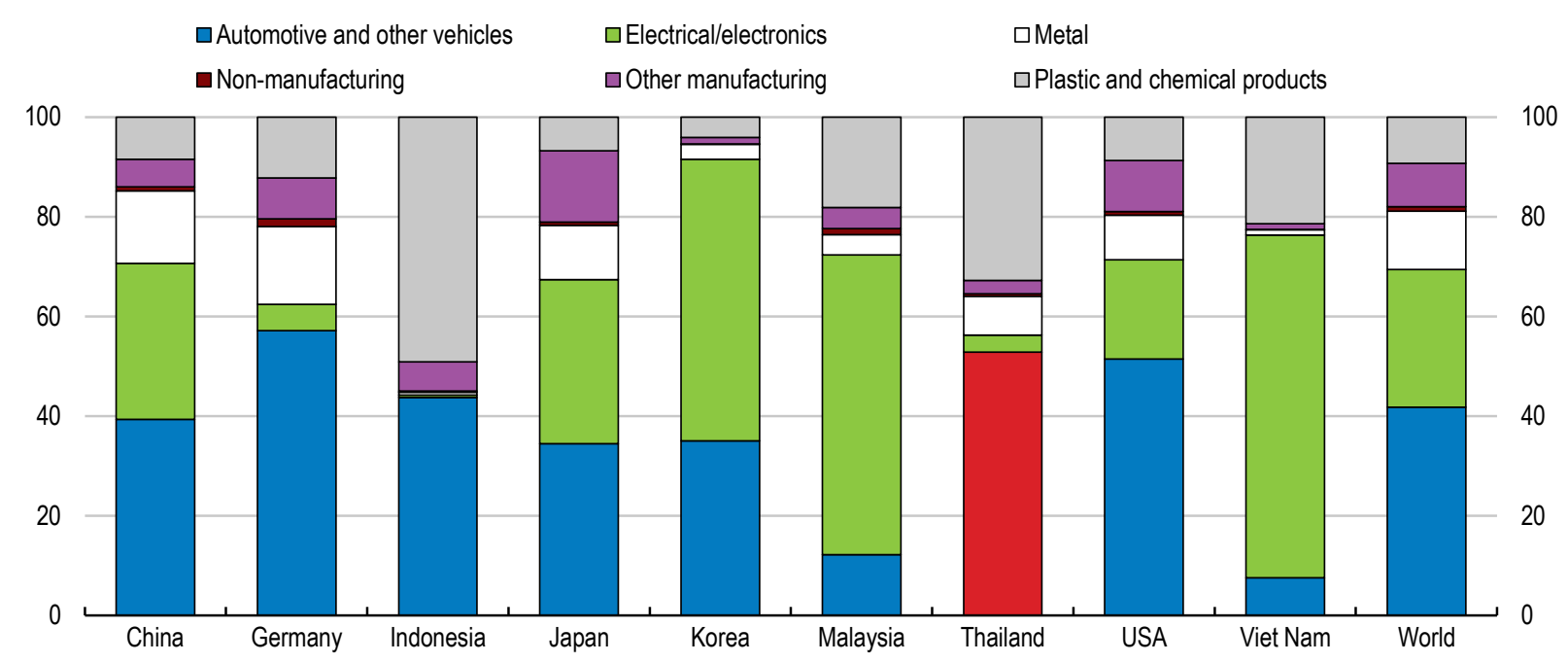

Note: Robot use in unspecified sector has been excluded from the calculation.

Source: OECD calculations based on data from the International Federation of Robotics (IFR), https://ifr.org.

7. Automation technology often substitutes for labour to carry out certain tasks, while complementing labour in other tasks. According to ILO estimates, three of five jobs in five major ASEAN countries (Cambodia, Indonesia, the Philippines, Thailand, and Viet Nam) face at least a $70 \%$ probability of automation (Chang and Huynh, 2016 $\left[6_{7}\right)$. Figures for individual countries range from $44 \%$ in Thailand to $70 \%$ in Viet Nam (Figure 3). Although Thailand's share is the lowest among the ASEAN countries chosen as comparators, this is similar to what is estimated for some OECD countries like Australia (40\%) and the United States (47\%). Moreover, new estimates that focus on tasks carried out in a job rather than the occupation, find that only around $14 \%$ of jobs on average across OECD countries face a high probability of automation (Nedelkoska and Quintini, 2018[8]). In addition to these, 32\% of jobs in OECD countries have high probability to undergo significant change in the way they are carried out.

8. In addition, OECD analysis highlights that the risk of job automation is higher among low-skilled workers, women, and workers at low-wage occupations, which may further increase disparities in the labour market (Nedelkoska and Quintini, 2018[8]). The studies suggest that the probability of automation is not evenly distributed across occupations, in Thailand, and that risks are particularly acute for occupations such as shop sales assistants, food service counter attendants, cooks, office clerks and accounting associate professionals (Chang and Huynh, 2016[7] $)$. However, these estimates only provide a projection of possible outcomes in terms of task automation in the next few decades. Many factors could limit technology adoption, including the relative price of technology and attitudes towards technology.

9. Furthermore, it is important to note that these figures only capture potential job destruction and do not account for the (potentially larger) number of new jobs that technology will create. While certain jobs may disappear, others will emerge and a sharp decline in overall employment is unlikely (OECD, $\left.2019_{[6]}\right)$. On the other hand, job automation certainly could bring large benefits to the economy, such as higher productivity and improved working conditions. For instance, safety and health at work can improve as hazardous jobs are automated. It could also help overcome labour shortages in the face of an ageing population. However, it is important to be aware of the huge impacts that technological advances can bring to the nature or the existence of a number of jobs. In order to maximise the benefits of automation and minimise the downsides, it is crucial to ensure that people are provided with sufficient re-skilling and upskilling opportunities. 


\section{Figure 3. Jobs with high probability of automation}

Share of jobs with high probability of automation or a probability of significant change

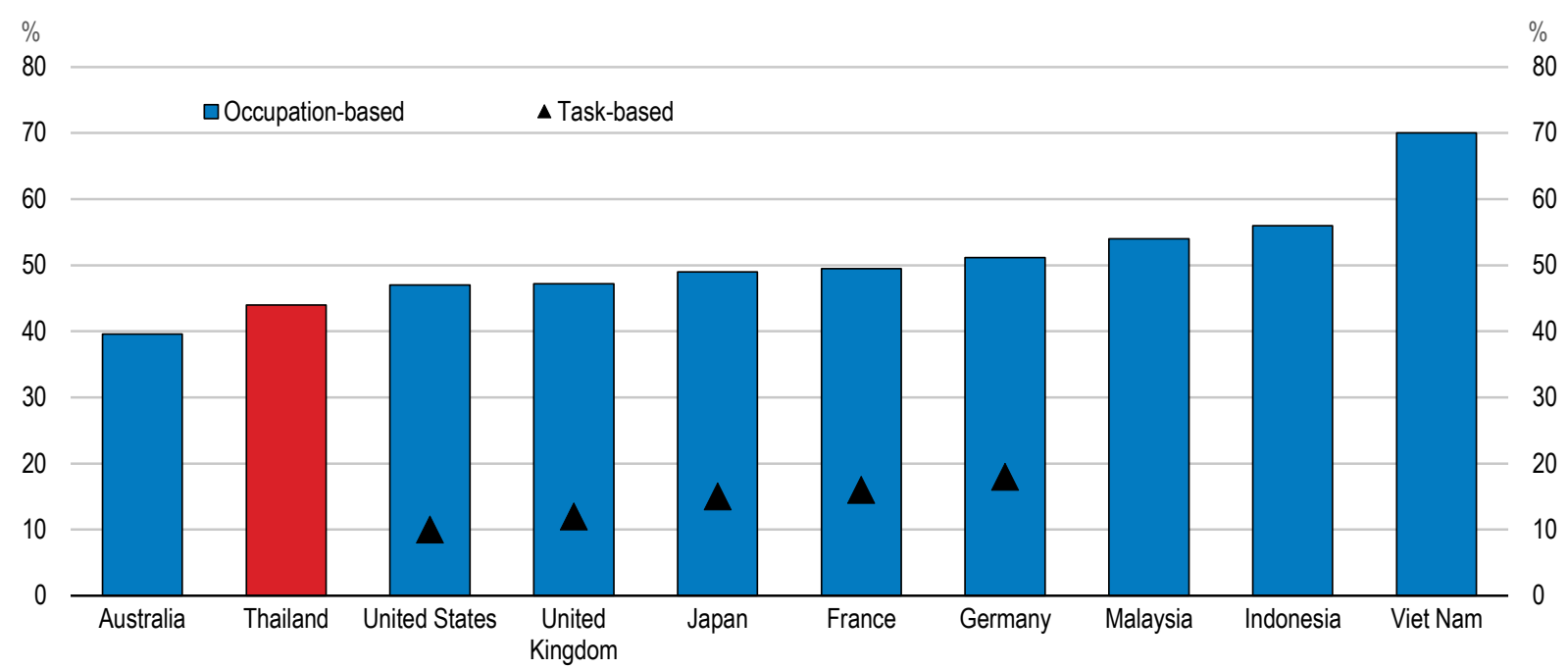

Note: Occupation-based estimates for the risk of automation are based on Frey and Osborne (2017), whereas task-based estimates come from Nedelkoska and Quintini (2018).

Source: L. Nedelkoska and G. Quintini (2018), "Automation, Skills Use and Training", OECD Social, Employment and Migration Working Papers, No. 202, Paris; C. Frey and M. Osborne (2017), "The Future of Employment: How Susceptible are Jobs to Computerisation?", Technological Forecasting and Social Change, Vol. 114, pp. 254-280; J. Bowles (2014), Chart of the Week: 54\% of EU Jobs at Risk of Computerisation, Bruegel blog post; Ceda (2015), Australia's Future Workforce?, Committee for Economic Development of Australia, Melbourne; J. Chang and P. Huynh (2016), "ASEAN in Transformation: The Future of Jobs at Risk of Automation", Bureau for Employers' Activities Working Paper, No. 9, International Labour Office, Geneva; Khazanah Research Institute (2017), "The Times They Are A-Changin': Technology, Employment, and the Malaysian Economy", Discussion Papers, No. 1/17, Khazanah Research Institute, Kuala Lumpur; and Nomura Research Institute (2015), " $49 \%$ of the Japanese Working Population Could be Replaced by Artificial Intelligence, Robots and Similar", News Release.

10. As technology is spreading across sectors and occupations, it becomes increasingly important for individuals to have strong digital skills. International data on digital skills and the use of digital technologies shows that youth and adults in Thailand have weaker digital skills than on average across OECD countries. For example, in $2014,17 \%$ of youth and adults in Thailand reported to have sent emails with attached files, compared to 50\% across OECD countries with available data in 2016/17 (UNESCO Institute for Statistics database). Only $5 \%$ of youth and adults in Thailand report to have used copy and paste tools to duplicate or move information within a document, compared to $56 \%$ in OECD countries. The growing demand for digital skills has accelerated in response to the COVID-19 crisis, as distancing measures lead to increased use of digital technologies for work and in daily life. To the extent possible from available technologies, the nature of work and the way tasks that were normally carried out is likely to change significantly in the postCOVID-19 world. It is expected that demand for digital tools that facilitate distancing and reduce personal contacts, such as video conferencing, internet banking, online courses, and teleworking, will rise. This will reinforce the importance of and demand for technological advancement and digital skills, and could possibly stimulate further automation.

\section{Population ageing is impacting skills supply and demand}

11. Technology-related job changes are occurring against the backdrop of rapid population ageing, which is particularly fast in Thailand compared to other ASEAN countries (Teerawichitchainan et al., 2019[9]). According to the recent UN data, in Thailand, there were seven persons aged 65 and over for every 100 people of working age in 1980 and this number more than doubled by 2015. Furthermore, it is 
projected to more than triple between 2018 and 2050 (Figure 4), reaching about 51.1\% in Thailand in 2050, compared to $48.8 \%$ on average in OECD countries.

\section{Figure 4. Thailand is one of the most rapidly ageing countries}

Old-age dependency ratio

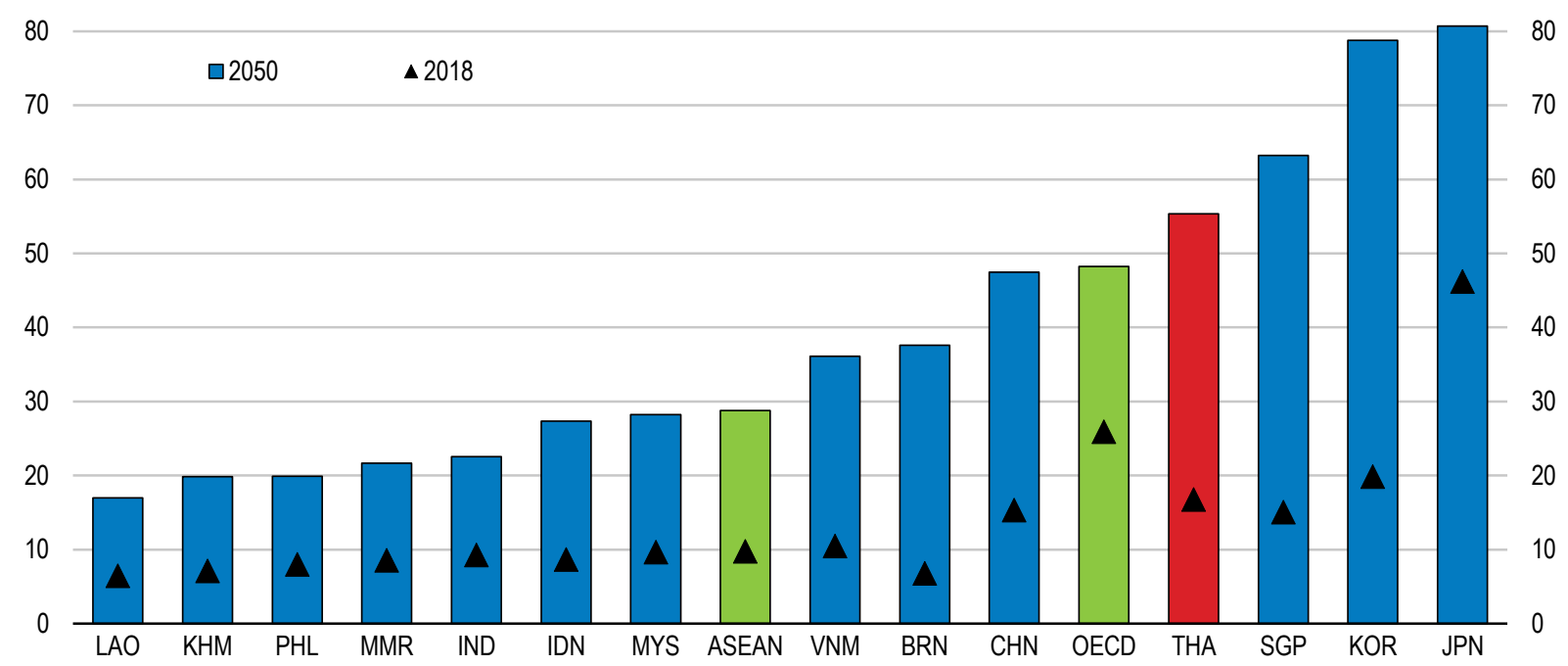

Note: The old-age dependency ratio is defined as the number of persons aged 65 and over relative to the 20-64 years old population. Source: United Nations, Department of Economic and Social Affairs, Population Division (2019). World Population Prospects 2019, Online Edition. Rev. 1.

12. Rising living standards, combined with the availability of higher quality healthcare services, have led life expectancy at birth to increase around the world. Data from the United Nations' 2019 World Population Prospect shows that, in Thailand, life expectancy has increased from 61 years to 77 years old between 1970 and 2015. Going forward, it is projected to increase to 83 years by 2050, possibly thanks further improvements in the diagnosis and treatment of diseases which are anticipated to become available in the future (Sanders, 2016[10]; Broad Institute, 2018[11]). On the other hand, decreasing birth rates is another crucial factor that accelerate demographic changes in Thailand. According to the recent World Bank data, the birth rates in Thailand has been in steady decline since 1960. Over two decades between 1965 and 1985, Thailand's birth rates per 1000 people plunged from about 40 to 20. Currently, its birth rates is about 10 , which is one of the lowest at the international comparison, contributing to rapid rise of dependency ratio in Thailand.

13. These demographic trends affect the labour market in terms of consumption patterns and technology adoption. In countries with rapidly ageing populations, such as Thailand, consumption pattern are expected to show substantial changes. Demand will likely shift from durable goods (such as cars) towards services such as health care and leisure. The recent COVID-19 pandemic has already shown that the demographics of countries are a key factor in the demand for infrastructure and skilled labour in the health sector. Moreover, as the number of retiring older workers rises relative to the number of young people entering the labour market, shortages of qualified labour may arise. This problem could be particularly relevant to the small open economy, such as Thailand, where aggregate labour demand is less influenced by its domestic market size. This could potentially lead to particularly fast adoption of industrial robots, preventing slower economic growth otherwise associated with an ageing population (Acemoglu and Restrepo, 2017 $[12])$. All of these factors will have an impact on the types of jobs that will be created and the skills demanded (OECD, 2019[6]). 
14. Population ageing and resulting skills shortages may also create stronger pressure to attract more immigrant workers. Thailand has been accepting a large number of migrant workers for decades, particularly from its neighbouring countries - Cambodia, Laos and Myanmar. According to the estimations of the International Organization for Migration (IOM), Thailand is one of the top migration destination countries in the world. It estimates that about 4898461 non-Thai people resided and worked in Thailand in 2018 (IOM, 2019 $\left.{ }_{[13]}\right)$. While migrants may help Thailand to overcome skills shortages, evidence found in OECD countries suggests that there are some key risks, as a significant share of migrant workers are irregular workers and/or have low skills level, conveying a high risk of low productivity and low inclusiveness (OECD, 2017[14]).

\section{Globalisation changes the structure of the labour market}

15. In conjunction with the diffusion of new technologies, the world economy has become increasingly integrated through international trade. As a share of GDP, international trade has risen across the world, both in developed and emerging countries in recent decades (Figure 5). Many emerging economies, including Thailand, are now major players in the world market, both as exporters and importers. Industrial production has become increasingly integrated at the international level, with the world economy organised in global value chains (GVCs) whereby the different stages of the production process are distributed across countries and regions (OECD, 2019[6]).

16. Thailand actively participates in GVCs. Climbing up its place on the value-added ladder would further increase the demand for high-skilled workers. The role of inward Foreign Direct Investment (FDI) in stimulating high skill job creation has been well documented. Multinational corporations tend to demand higher skill levels than do local companies, creating more job opportunities for highly skilled workers. Moreover, in addition to the possibility of formal knowledge and technology transfer, FDI comes with a high potential for "spills-overs" to the local economy (Blomström and Kokko, $\left.2001_{[15]}\right)$. Evidence shows that FDI spill-over effects have been significant in upgrading the skill level of the local economy in Thailand, reinforcing the demand for high skilled labour. (Srithanpong, 2014[16])

17. However, more recently, a new challenge has arisen for Thailand due to international trade tensions triggered by the recent COVID-19 crisis. The pandemic has made it difficult to keep GVCs going. The limited mobility of people and lockdowns do not only limit available air cargo and containers, but it also increases time and cost of a variety of other trade processes, from unloading shipments, physical inspection of goods, to testing and certification of goods and anti-dumping investigations. Over 50 countries have changed port protocols in response to COVID-19, ranging from port closure and quarantine measures to additional documentation requirements and examination. More generally, all supply chains are being affected by the need to ensure additional health and safety measures for all participants in the supply chain, raising the time and cost of production (OECD, 2020[17]). Furthermore, while trade may rebound when the situation improves, there may be longer term, structural effects. Some firms may retreat from globalisation, seeking shortened supply chains and suppliers located in countries that seem less prone to disruption or they may re-shore manufacturing (OECD, 2020[18]). These changes could have substantial impact on the Thai economy. 
Figure 5. International trade keeps rising

Trade in goods and services, as a percentage of GDP
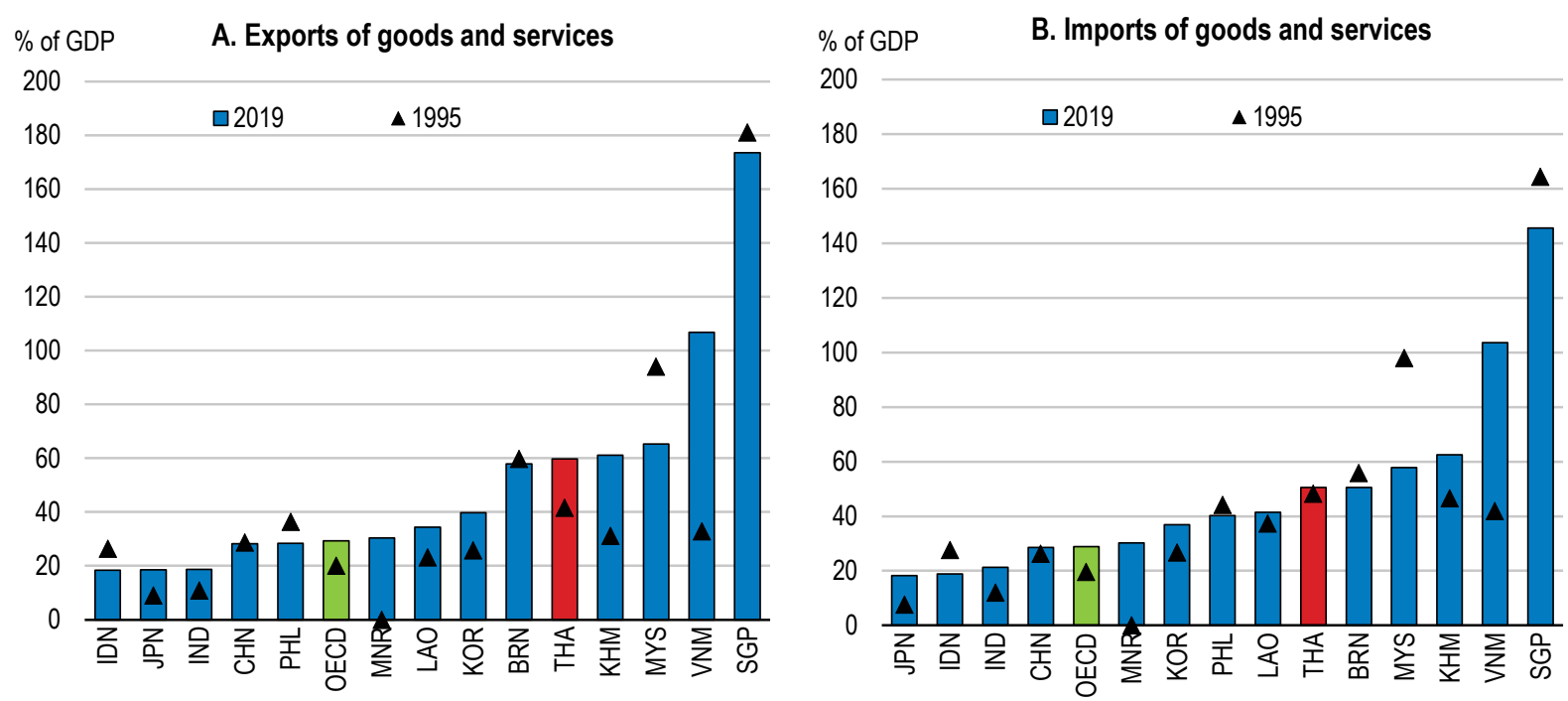

Note: For Myanmar, 1995 refers to 2000 , which is the earliest year available.

Source: World Bank, World Development Indicators Database.

\section{Skills development as the driver of Thailand 4.0}

\section{Access to education has been on the rise, but challenges remain}

18. Thailand has made remarkable progress in expanding access to education over the past decades, with potential to importantly help drive forward "Thailand 4.0", a government strategy aiming to move towards more skilled and technology-oriented economy in order to respond to the country's shrinking labour force by increasing the population's productivity (IECF Monitor, $2017_{[19]}$ ). Participation in general education in Thailand is relatively high, particularly at the primary level, with access to primary education nearly universal. The net enrolment rate, which measures the number of children of official primary school age who are enrolled in primary education as a percentage of the total children of the official school age population, stood at $99.6 \%, 3$ percentage points higher than in 2009 and comparable to that of high-income economies, such as New Zealand, Korea and Australia (Figure 6). Thailand also shows good results in student progression, showing a grade completion above $90 \%$ for the last grade of primary education (UNESCO-UIS, 2019[20]).

19. Thailand's enrolment rates in secondary education are in line with the middle-income countries in the region, but still comparatively lower with respect to OECD countries. For example, in 2015, and as shown in Figure 6, secondary enrolment was $77.3 \%$, just below Indonesia, Brunei and Singapore and above the ASEAN average (70\%). These figures are considerably lower than high-income OECD countries, such as Korea or Australia, which exhibit enrolment rates above $90 \%$ in secondary education. In order to boost secondary enrolment and completion rates, Thailand could consider learning from other countries in designing its second chance learning options for early school leavers (Box 1). 


\section{Box 1. International examples of second-chance learning options for early school leavers}

Early school leavers typically find it very hard to return to school, as the educational, social or personal factors that caused the initial drop-out often persist and remain an obstacle. Depending on their level of schooling and how long it is since they dropped out, young people may also lack the elementary literacy and numeracy skills required to continue schooling or follow a professional training programme.

Second-chance programmes offer a flexible learning environment - often with a residential component - that is well adapted to early school leavers' needs and designed to help them back into education. They typically combine catch-up classes in literacy and numeracy skills with vocational classes, intensive counselling, health support and career guidance. Simple work experience or community work components - in catering or elderly care, for example - can help them re-gain their work rhythm.

Probably the largest and best-known second-chance programme is the US Job Corps, which has been operating since 1964. It targets disadvantaged 16-to-24 year-olds, giving them academic tuition, vocational training, counselling, and social skills training. It also provides health care and organises job placements. Another important programme - and one that has expanded internationally from the United States - is YouthBuild, which provides skills and work experience in the construction sector. Both schemes rely on strong ties with local employers. Both contain a strong non cognitive training component aimed at strengthening motivation, building conscientiousness, and coaching young people in interpersonal skills. For some young people, the US Job Corps and YouthBuild function as comprehensive pre-apprenticeships, while for others they are stepping stones to higher education.

In France, the École de la Deuxième Chance offers similar curricula. The Swedish Folk High Schools provide young people aged 18 and over with a mixture of intensive counselling, coaching in social and life skills, and formal education. They use their own grading system that measures not only academic performance but also social skills, and public universities set aside quotas for Folk High School graduates. In Australia and the United Kingdom, smaller-scale second-chance programmes are offered in so-called "youth foyers", which offer training, accommodation and social and psychological support to homeless young people, and which are often located close to the vocational training facilities.

Source: OECD (2016[21]), Society at a Glance 2016: OECD Social Indicators, https://dx.doi.org/10.1787/soc_glance-2016-4-en

20. While enrolment rates in education have increased over the past decade, many students from the poorest families still do not attend school in Thailand (UNESCO-UIS, 2019[20]). Rates of exclusion are higher in rural areas and among various ethnic and linguistic communities. Despite renewed efforts since the 1990s, access to education for children with disabilities also remains limited in Thailand (OECD/UNESCO, 2016[22]). To promote enrolment among disadvantaged students, Thailand expanded free education from 12 to 15 years in 2009 and free schooling now extends from pre-primary to upper secondary education. However, the new policy does not cover transportation costs, which are one of the main factors hindering educational access for poor students living at further distance from schools (OECD/UNESCO, 2016[22]). Regional disparities are likely to prominently resurface in the context of COVID-19, with potential to importantly exacerbate existing inequalities. As schools have closed amidst the pandemic, reduced access to digital technologies for pupils in rural areas further disrupts their equitable participation in the learning process which has been largely moved online (Kenan Foundation Asia, 2020[23]) (See Box 2 for addition details on Thailand's response to COVID-19). 


\section{Box 2. Thailand's education policy response to COVID-19}

On 17 March, the Ministry of Education (MOE) of Thailand announced that all educational institutions, both government and private, would temporarily close, to reduce the spread of COVID-19, thus leading students to complete the academic year from home. The anticipated date for re-opening of schools has been set to 1 July - therefore, the start of the first academic semester for 2020 would be delayed from 16 May to this date.

To ensure the safety of students and reduce the risk for students not to return to schools, the MOE has established a mandatory list of 42 items in place that each school must implement two weeks before re-opening. These 42 items cover school safety measure, such as the minimum amount of meters squared per students, daily temperature checks protocols, floor markings to ensure distancing, compulsory masks and frequently daily cleaning of all school facilities.

To alleviate the financial costs of meeting these mandatory health requirements, the Private Education Commission has come up with special loans of up to THB 500000 to relieve some of the pressure on private schools. Schools were instructed to switch to online learning immediately upon school closings on 18 March. In the face of technological limitations to online learning - many households lacked devices, a stable Internet signal (particularly in rural areas), and time to monitor students - the government has identified that the next best strategy to keep students and parents engaged in the learning process is to send teachers on personal households visits. While involving a larger budget for worksheets, fuel costs and teacher allowances, government has decided to cover these expenses under the Thailand 15-Year Free Education Scheme.

21. Despite progress in recent years, Thailand - like most countries in the region - lags behind OECD countries in terms of access to pre-primary education. While government policies to expand free access have increased enrolment in pre-primary education, there is still room for improvement in coverage, as approximately $25 \%$ of children ages 3 to 5 are not enrolled (NESDB, 2017[24]). Further, the student population who are not enrolling are also disadvantaged students who, as research suggests, stand to benefit the most from pre-primary education. This is supported by the OECD 2015 PISA results, which reveal that Thai students who attended two to three years of pre-primary education scored 30 points higher on average as compared to those who did not attend at all (PISA, 2015[25]). Overall, Thailand performs around the regional average, with a net enrolment rate of $53.2 \%$ in 2017 , slightly above the ASEAN average of $50 \%$, but significantly below OECD countries in the Asia-Pacific regions, such as New Zealand and Korea (Figure 6). 
Figure 6. Thailand's participation in formal education is around the regional average

Net enrolment rates, by level of education, 2018 or latest data available

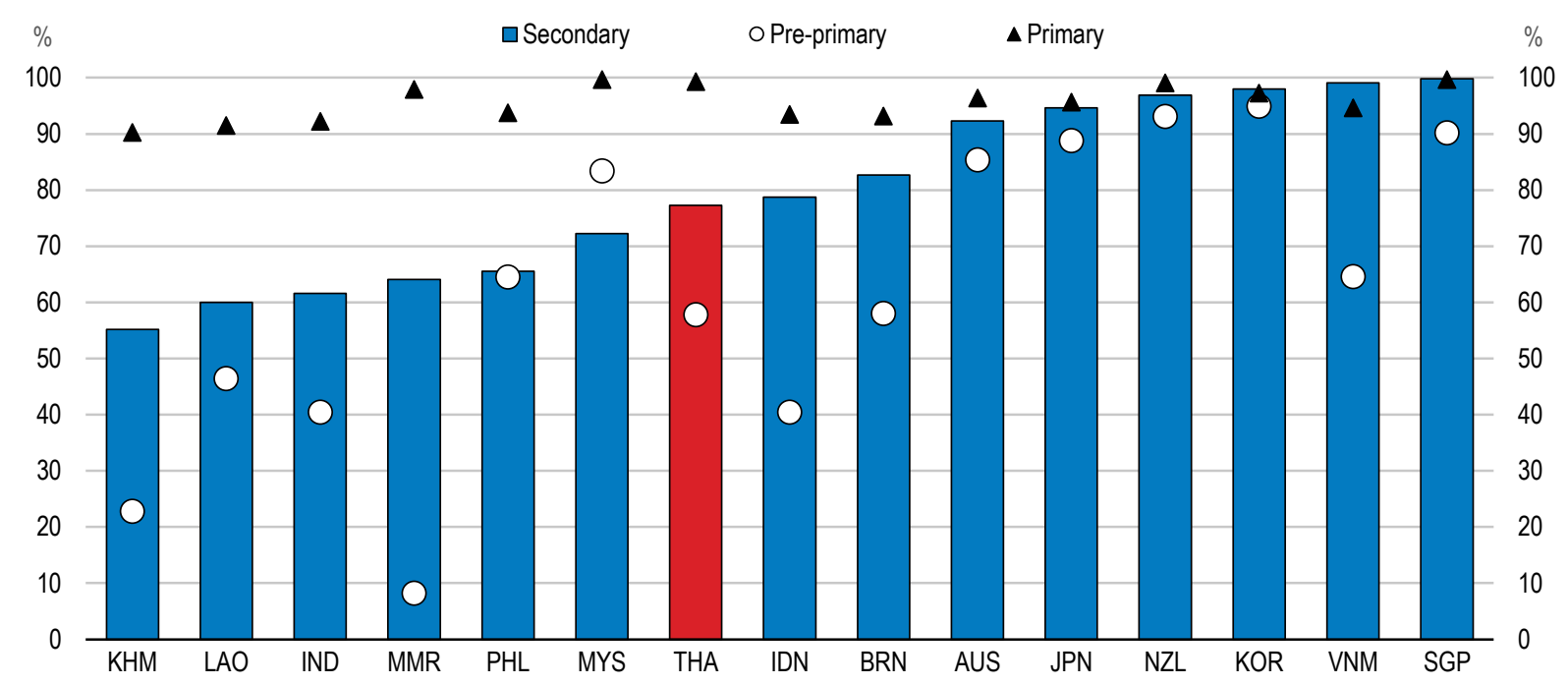

Note: For Cambodia and Viet Nam, the secondary level ratio was proxied by lower secondary ratio. For Thailand, the primary level ratio refers to 2009 .

Source: UNESCO, Education Database.

22. The expansion of Thailand's education system is the result of strong and sustained financial investments, as also reflected by the importance of education in the state's budget. Thailand invests a significant share of its national wealth in education, and over the last decade, it has consistently allocated around $20 \%$ of total government expenditure to education each year.

23. Overall, the level of spending on education in Thailand is above the average, when compared with other countries in the ASEAN region (Figure 7). In 2013, its spending share on education of $4.1 \%$ of GDP is considerably higher than Indonesia and the Philippines, although below Malaysia and Viet Nam. On the other hand, when compared with the OECD countries, whose spending is on average around $5.5 \%$ of GDP, Thailand is still below this level of spending (UNESCO-UIS, 2019[20]).

24. Significant efforts to expand pre-primary education in Thailand are reflected in relatively high investments as a percentage of GDP - both compared to neighbouring countries with a similar level of development, and to more highly-developed countries in the region (OECD/UNESCO, 2016[22]). However, Thailand's government expenditure on pre-primary education as a percentage of GDP has remained quite stable in recent years (UNESCO-UIS, 2019 [20]), and further efforts are needed to ensure that it reaches the most vulnerable populations, while increasing its quality and impact (see below).

25. Thailand's expenditure on primary education is the highest among the selected countries in the region, and is the predominant source of education expenditure in the country. In 2012, Thailand's funding per primary student was $29.4 \%$ of per capita GDP, compared to $15.4 \%$ in Malaysia (as of 2011 ) and $11.2 \%$ in Singapore. In that year, $44.8 \%$ of Thailand's government education spending was directed at the primary level, a higher proportion than in any of the other selected countries (UNESCO-UIS, 2019[20]). At the secondary level, although government expenditure increased from $14.3 \%$ of the total in 2008 to $28.6 \%$ in 2012 , the per-student funding remained low compared to many of the selected countries, at $19.7 \%$ of per capita GDP.

26. However, as most OECD research shows, beyond a certain level of expenditure, educational and skills outcomes (e.g. PISA scores, cognitive skills) tend to be more correlated with other inputs, such as 
teacher quality or curriculum. The following section will discuss several actionable factors that may be limiting the ability of these efforts to translate into positive results.

\section{Figure 7. Thailand's expenditure on primary education is the highest in the region}

Total public expenditure on education, 2018 or latest year available

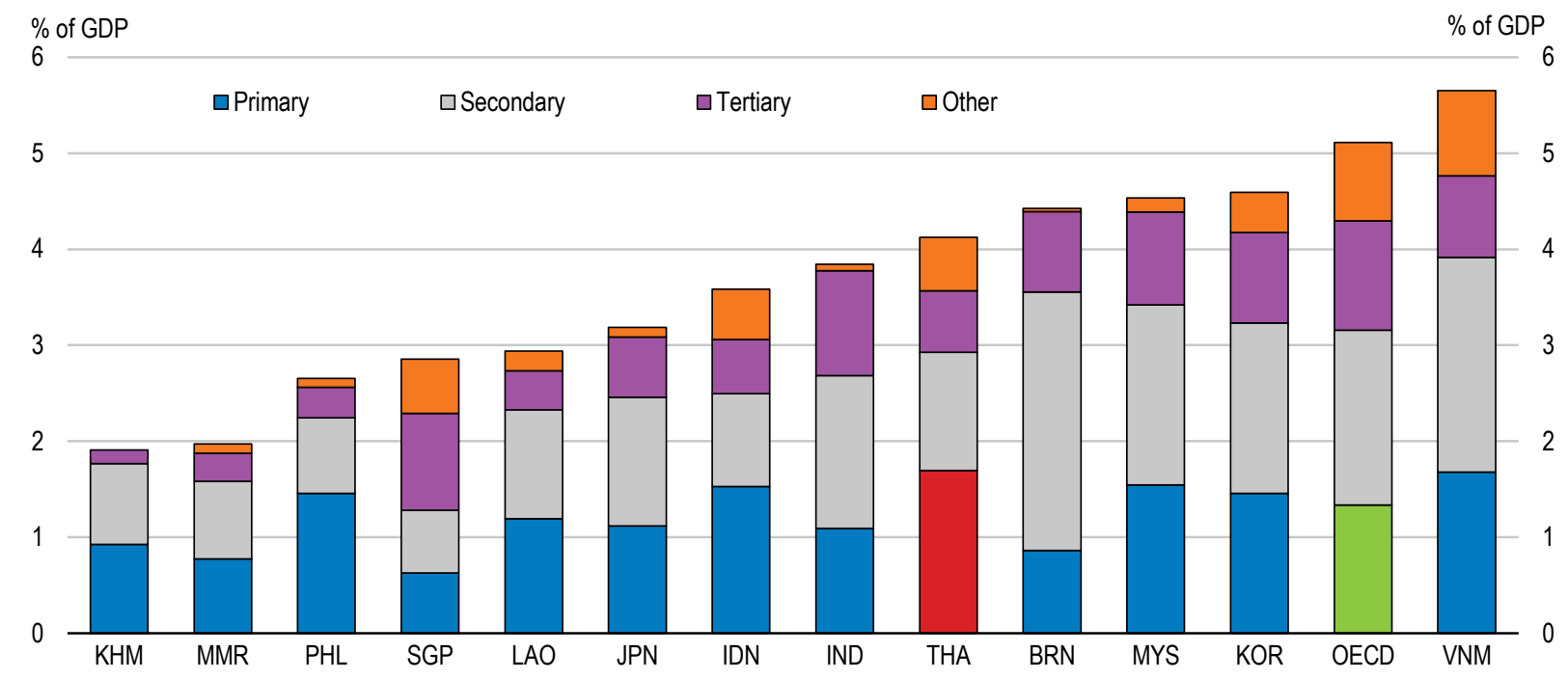

Source: World Bank, World Development Indicators Database.

\section{Reducing regional disparities and improving education quality}

27. As highlighted in the section above, Thailand has made considerable efforts with respect to investment into and expansion of its education system. However, it is unclear whether the ambitious endeavour has successfully led to the anticipated gains. The 2018 PISA results reveal that 15 year-old students in Thailand achieve lower scores in all three domains measured by the Programme for International Student Assessment (PISA) - reading, science and mathematics - than do their peers in the OECD on average (Figure 8). While the reading performance of Thai students lags behind the OECD average by 90 points, the gap equals 70 points for mathematics and 63 points for science (OECD, 2019[26]). In comparison to other ASEAN countries that participated in the 2018 PISA assessment, the scores of Thai 15 year-olds in reading lag behind those of Brunei Darussalam, Malaysia or Singapore. Further, the same ranking holds with respect to science and mathematics as well (OECD, 2019[26]). In Thailand, as well as in all OECD countries, girls have historically outperformed boys in all subjects in the PISA test. However, the gender gap is significantly higher than in OECD countries. For example, in 2018, girls scored 39 points higher in reading, equivalent to half a standard deviation. Similarly, girls outperformed boys by 16 and 20 points in mathematics and science (16\% and $20 \%$ of a standard deviation), respectively. 
Figure 8. PISA scores are lower than the OECD average, with a growing gap in reading

A. PISA scores over time

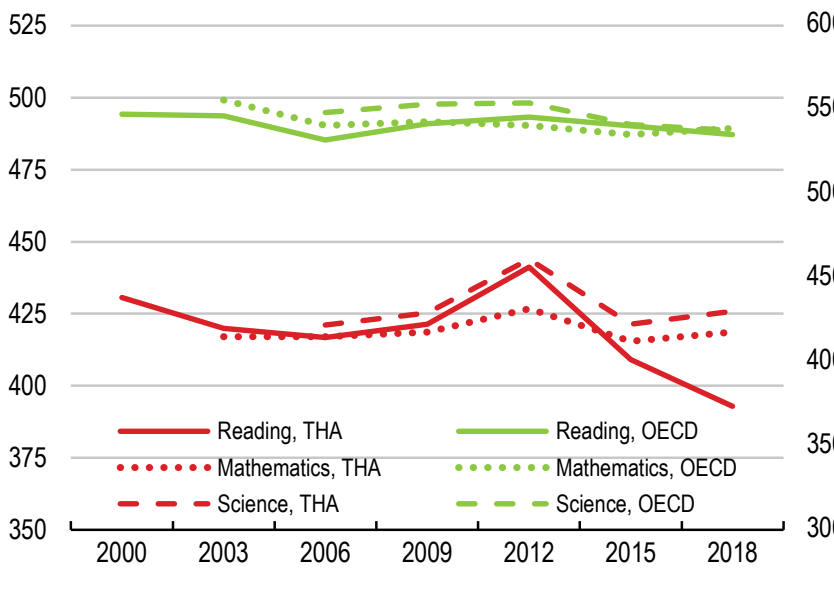

B. 2018 PISA scores relative to peers

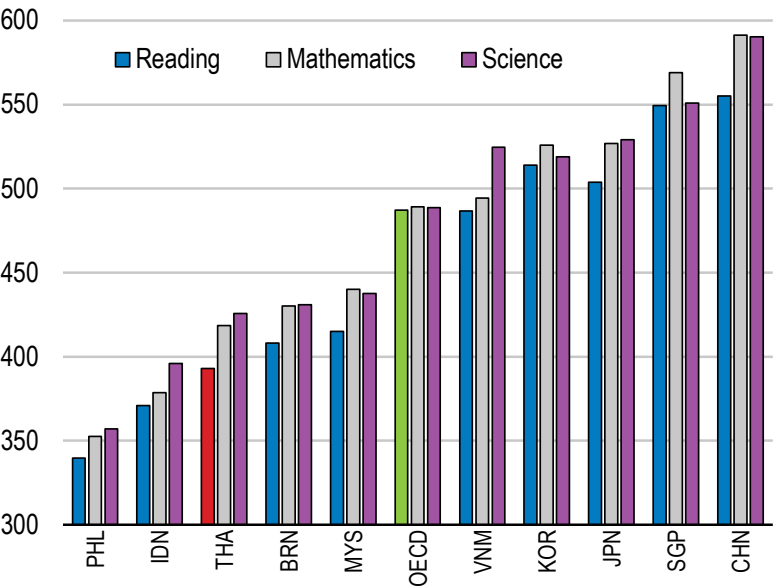

Note: Data for Viet Nam refer to 2015

Source: OECD (2019[26]), PISA 2018 Results (Volume I): What Students Know and Can Do, https://dx.doi.org/10.1787/5f07c754-en

28. Compared to the OECD average, Thailand also counts a smaller and decreasing proportion of topperformers in reading (students performing at Levels 5 or 6 of proficiency), and a larger and increasing share of low-achievers (students performing at or below Level 2 of proficiency) (Figure 9). For example, while the proportion of low-performers in reading is roughly $23 \%$ in the OECD on average, Thailand's figure stands at almost $60 \%$ (OECD, 2019 $[26]$ ). Thailand also falls well below the ASEAN countries' PISA reading average of 413 points (which corresponds to a Level 2 of proficiency), with a score of 393 (Level 1 proficiency) (GovTech SEA, 2019[27]).

29. While the performance scores marked a slight, albeit non-statistically significant improvement with respect to science and mathematics between 2015 and 2018, reading performance was lower in 2018 than in any other of the previous PISA rounds - there was a statistically significant drop by 16 points from 2015 (Figure 8). In terms of the average three-year trend in performance across PISA rounds since the earliest assessment available, the performance of Thai students remains stable for science and mathematics $\left(\mathrm{OECD}, 2019_{[28]}\right)$. On the other hand, a negative average three-year trend can be identified with respect to reading (Figure 8 ). 
Figure 9. Thailand has a high share of low achievers and a low share of high performers in reading Proficiency level in reading
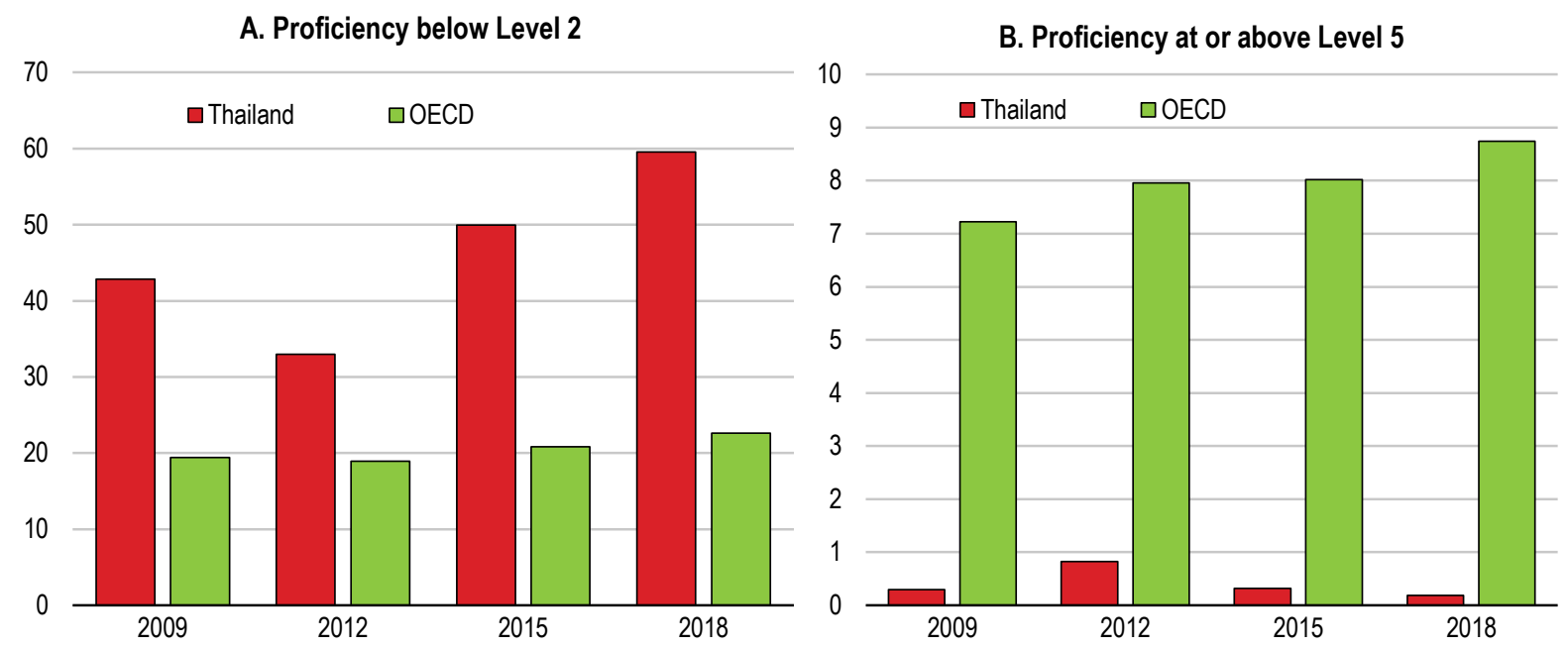

Note: The low achievers are defined as those with less than 407.47 score points (Level 2) and the top performers are those with 625.61 score points (Level 5) or above.

Source: OECD (2019), PISA 2018 Results (Volume I): What Students Know and Can Do, https://dx.doi.org/10.1787/5f07c754-en, Table I.B1.7.

30. There are several factors that may explain the decline in learning abilities in Thailand's student population, while their consideration has potential to help further advance the Ministry of Education's fiveyear strategy seeking to prepare the young generation for the requirements of 21 st century learning, especially through boosting numeracy and literacy skills in both national standardised tests and international assessment programmes. One important limitation is the lack of qualified teachers in rural sectors. According to an evaluation by the Office for National Education Standards and Quality Assessment, approximately $20 \%$ of Thai schools in rural areas do not pass minimum quality standards (OECD, 2013[29]). A contributing factor is the low supply of qualified teachers in the rural sector. Although all teachers in Thailand are obliged to possess an undergraduate degree, a recent World Bank report (Lathapipat, 2017[30] ) highlights that while one out of five teachers in Bangkok also has a graduate degree, only one out 11 teachers has graduate degree in the Mae Hong Son province, where schools are smaller in size on average. In addition, teachers in Bangkok have more years of experience on average, and Bangkok's schools have more teachers per classroom. In the context of COVID-19, the importance of qualified pedagogical workforce with adequate teacher training becomes further magnified especially with respect to teachers' preparedness to use online tools for e-teaching amidst school closures (See Italy's and Germany's responses to keep students learning and connected with their teachers in Box 3). At present, majority of Thai teachers have not taken part in training of this sort (Kenan Foundation Asia, $2020_{[23])}$. 


\section{Box 3. How are OECD countries dealing with school closures during the pandemic?}

\section{Italy's pedagogical response}

Italy has opted for a strategy of investing in digital devices to reach the most vulnerable populations of students across Italy. In order to reduce the risk of an increase in educational inequity, disengagement in learning, and ultimately dropout rates, the Ministry of Education of Italy has so far allocated approximately EUR 70 million for schools to buy digital devices. According to the National Institute of Statistics in Italy, one-third of Italian families have no access to a tablet or a computer at home, a statistic which is on average higher in southern provinces of Italy. In more disadvantaged provinces, primary and secondary schools received additional funding to enable provide low-income families with equipment necessary for distance learning.

In addition, $25 \%$ of Italian families have a low connectivity speed which is insufficient for streaming or downloading educational content. To address this challenge, the Ministry of Education launch the initiative \#LaScuolaNonSiFerma ("The School Never Closes), consisting of a partnership with RAI - the national public broadcasting company - to diffuse education content in its RAI Scuola, Italian free-toair television channel, and Rai Play, a multimedia portal. The \#LaScuolaNonSiFerma will generate stand-alone content to support teaching activities for all grades, which can be accessed offline and televised. In addition, the initiative aims to safeguard the sense of school community between teachers, parents, and students, by generating content and a space that shares different experiences of distance learning and the stories of teachers, managers, staff, students and families.

\section{Germany's response in tackling dropout among VET students}

Germany has taken measures to tackle dropout rates for the education sector through initiatives to support vocational education and training (VET) learners at risk, including students from disadvantaged socioeconomic backgrounds, migrants and from ethnic minorities. The VET sector has been particularly vulnerable, as it is more focused on practical aspects that cannot be delivered easily due to lack of access to tools and other necessary equipment relevant to the learning process. In this context, Germany has recognised the special need for additional guidance for this student population. While many German VET educational providers and apprenticeship providers have moved online learning and online assessment during the pandemic, efforts such as the German PES Programme, a program for personnel management within the framework of extended self-employment of schools, are also offering additional funds to facilitate the needs of numerous self-employed guidance counsellors.

In addition, Germany has relied on "transition coaching" to provide individualised and psychological support for VET students to reduce risk of disengagement from learning in the population of VET students. There are currently 5000 transition coaches working with 3000 schools. Transition coaches, who are mostly pedagogues, support students to complete VET or other upper-secondary education by meeting with at-risk students regularly to manage the transition to post-graduation life by creating a transition plan in collaboration with students. During the pandemic, transition coaches have heightened their support by offering additional guidance by phone on issues, such as VET course choices and educational pathways.

Finally, the German government is also updating training for VET career guidance counsellors and introducing new online tools that address changing needs of VET student population.

31. From a policy perspective, the gap in teacher quality can be addressed by strategically increasing investments and re-structuring the incentives currently in place for teacher placement. The present teacher management system allows teachers to select their location once they have been in service for over two years, with salaries of teachers in remote areas being lower on average. This is partly driven by the fact 
that these tend to be younger and less experienced teachers compared to those working in cities. In this context, it is positive that Thailand has been working on improving the incentives in place for younger teachers. At the request of the Ministry of Education, the Ministry of Finance has agreed on providing financial support for rural teachers working in hardship locations, helping them to sustain their daily lives and hoping to encourage them to keep teaching in hard-to-reach locations for more than two years.

32. Furthermore, with COVID-19 necessitating using ICT advances to effectively design and lead remote learning, provision of teacher training on the use of digital tools should be strengthened. Finally, pre-primary teachers also need to receive more training and support to implement the standards-based curriculum (UNESCOIOECD, 2016[31]). The importance of adequate pedagogical teacher training at the pre-primary level is further exemplified in Box 4.

\section{Box 4. What matters during expansion of pre-primary education - Evidence from a randomised controlled trial in Colombia}

In Colombia, enrolment rates in pre-primary education increased from $13 \%$ in 1990 to $84 \%$ in 2015 , while in 2011 the government committed to triple expenditure in early childhood education. A recent study by Andrew et al., (2019) analyses the "Hogares Infantiles" (children's homes) programme, which provides pre-primary education to children from disadvantaged backgrounds aged five and younger. Using an experimental design, the authors show that investment in what is often called "structural quality" (e.g. physical infrastructure, staff resources, pedagogical material) alone does not produce the expected learning gains in students. The authors found that when greater resources are given to schools, teachers tend to substitute their efforts and involvement with children and delegate some responsibilities to less experienced and less qualified teaching assistants. The study shows that these children saw no improvements in their cognitive and social-emotional development on average, and that for some children the effect was even negative.

In contrast, when structural quality was paired with pedagogical training for teachers, children's cognition, language and school readiness increased by around 0.15 of a Standard Deviation (SD). Larger gains $(0.3 \mathrm{SD}$ ) were observed among the most disadvantaged children, offsetting the negative effect on teacher behaviour.

Source: Andrew, A. et al. (2019[32]), Preschool Quality and Child Development, www.nber.org/papers/w26191.

33. Beyond differences in teacher quality between urban and rural sectors, there are other disparities that are visible along geographical divisions, such as insufficient material resources and physical infrastructure. For instance, the difference in PISA performance between a village and a large city is approximately 1.4 points on the material resources index and 0.6 points on the physical infrastructure index (OECD, 2013[32]). As gaps in physical infrastructure and learning material contribute to low the quality of teaching instruction, future increases in public education expenditure should be oriented towards reducing these gaps as well. At the level of formal and non-formal pre-primary education, a standardised monitoring system would be essential to improving the quality of instruction, as it enforces standards, identifies centres that are not meeting these, and provides them with additional resources and support to improve upon them. Against this backdrop, Thailand's recent establishment of the Equitable Education Fund (Box 5) holds potential for improvement by targeting support at disadvantaged children and students, as well as teacher development, across all levels of education. 


\section{Box 5. Thailand's Equitable Education Fund}

The Equitable Education Fund (EEF) was established in 2018 under the Equitable Education Act 2018 with the objective of providing financial support for children and youth who are in greatest need, reducing education inequalities by forming partnership with relevant stakeholders and systematically supporting teachers' quality. The EEF falls under the supervision of the Prime Minister, and is governed by a multi-sectorial Board of Governance, including five Ministries (Education, Finance, Social Development and Human Security, Interior and Public Health) and six independent experts from various disciplines (academic, private sector and civil society).

The EEF focuses on supporting disadvantaged youth across all levels of education (including higher education), as well as children (3-17 years old) out of school. In its first year, the Fund offered supported to 510630 underprivileged students. Firstly, the EEF works to improve access, quality and learning outcomes of early childhood care and education services, especially for the poorest and disadvantaged children through research and technical assistance. Secondly, through conditional cash transfers, the EEF covers education-related expenses until the completion of basic education, with the support of roughly 569000 underprivileged primary and secondary aged students among its current priorities. Thirdly, in order to reach the estimated 670000 out-of-school children, the EEF works to develop effective strategies at the provincial level across 15 provinces, collaborating with stakeholders to create learning opportunities flexible enough to meet provincial education and employment needs while aligned with the UNESCO's suggestions on flexible learning strategies. Moreover, with respect to teacher development, the EEF carries out research on ways to enhance teachers' skills, while supporting the establishment of prototype institutes that provide professional teacher training.

Subscribing to a collaborative strategy inclusive of stakeholder engagement, the EEF also promotes and assists agencies, whether from the public sector, private sector or civil society, that are involved in working with underprivileged children and students.

Source: The Equitable Education Fund (2020[33]), What We Do, https://www.eef.or.th/en/eef/\#about-en

34. Finally, while Thailand has shifted from a content-based curriculum to a modern standards model that identifies specific knowledge areas the student should master for each subject area, the curriculum itself is not coherent and schools and teachers have not been able to implement it fully. This indicates a need to invest further in teacher development and preparation to cover the new curriculum and to better articulate the curriculum subjects with one another. Similarly, the newly established pre-primary curriculum should be reviewed to improve clarity, consistency, and relevance (OECD/UNESCO, 2016[22]).

35. In this context, Thailand's efforts should be directed towards improving structural factors that hinder the development of the right skills that respond to changing skills needs. Additional efforts should be made not only to increase the average level of skills of Thai youth - which are still low in international comparison as discussed above - but also to reduce the existing inequalities that prevent students from disadvantaged backgrounds to develop their full potential.

\section{Supporting HEls innovation and alignment of students' educational choices with labour market needs}

36. Since the 1990s, significant expansion of higher education has occurred in Thailand, leading to a so-called education "massification", a term used to describe a situation of higher education enrolment extending beyond the nation's elite (Crocco, 2018[34]). During this time, the student enrolment rate has 
increased from less than 20\% in 1995 to roughly 50\% in 2016 (Figure 10), one of the highest rates in the region, although still lagging behind the OECD average by more than about 20 percentage points.

\section{Figure 10. Higher education enrolment has increased until recently}

Gross enrolment rate in tertiary education, per cent

\section{A. Enrolment rate trends}

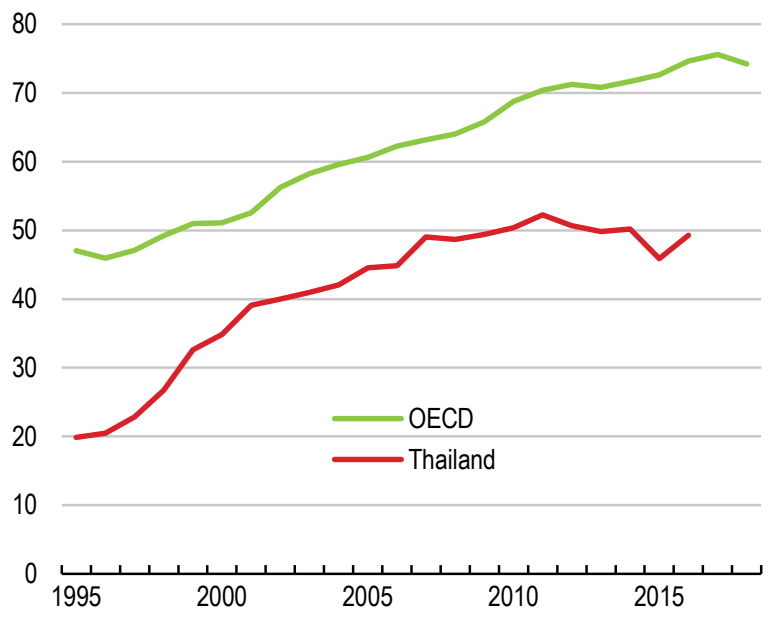

B. Enrolment rate comparison

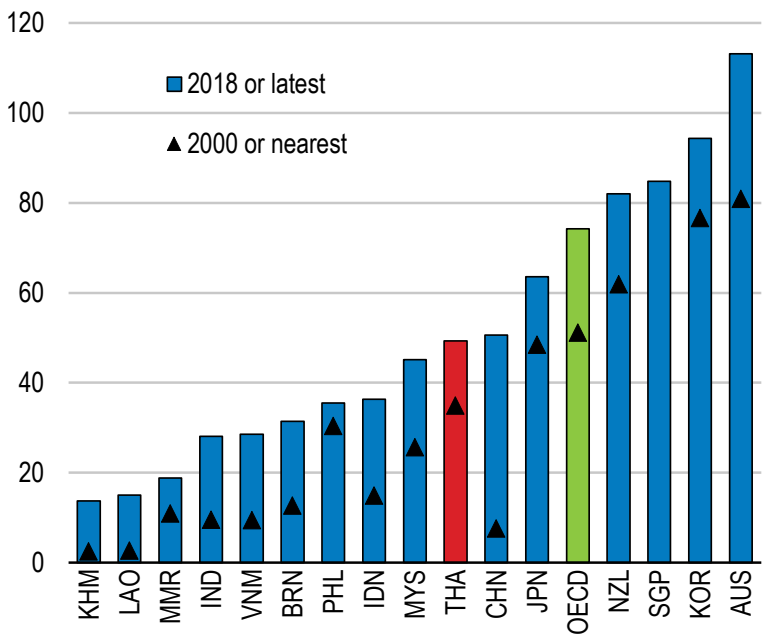

Note: The gross enrolment data shown above is calculated as the number of students enrolled in a given level of education, regardless of age, expressed as a percentage of the official school-age population corresponding to the same level of education. Gross enrolment rates can be over 100 because the number of students enrolled in a given education level may often include students that have an age above or below the age that officially corresponds to that education level.

Source: World Bank, World Development Indicators Database.

37. The historical increase demand for higher education has also been reflected in the increasing numbers of higher education institutions (HEIs) being opened, especially through the establishment of new private HEls, and to a lesser degree through the restructuring of some public ones (IECF Monitor, 2017[19]). In 2018, around 310 universities, colleges and tertiary academic institutions operated in Thailand.

38. However, after a high point in 2011, fluctuations in the enrolment rate began to surface (Figure 10) due to demographic challenges and a rapidly ageing population (Michael, 2018[35]). By 2040, it is projected that roughly $25 \%$ of the Thai population will be 65 years of age or older, with the number of tertiary education-aged students expected to sharply decline too (IECF Monitor, 2017 ${ }_{[19]}$ ). In the 2018 admissions period, universities opened 156216 spots for prospective students. However, only 105046 took the entrance exams, leaving more than 50000 places empty (Asian Correspondent, 2016[36]).

39. A rapidly ageing population and a shrinking student population present a challenge for HEls to sustain enrolment rates and cover their costs. In order to increase competition within the higher education market in Thailand and boost the quality of HEls and their alignment with labour market needs, overseas institutions, such as Carnegie Mellon University or National Taiwan University, have been invited to open branch campuses in Thailand. While the latter aims to offer courses in advanced engineering, the former is planning to open logistics engineering programmes, tying well into the objectives of "Thailand 4.0".

40. In order to thrive amongst the heightened competition, Thai universities should be focusing on modernising their teaching methods in order to simplify course attendance for students and increase the provision of courses targeting the adult population. The use of online learning technologies is already prominent amongst many overseas HEls as well as certain employers, offering cheaper and easier-to- 
access courses attractive for an increasing number of students (Bangkok Post, 2019[37]). Given the disruptions to in-person attendance and university shutdowns brought about by the COVID-19 public health crisis, the importance of universities' investments into more technology-intensive options for delivering courses becomes further underlined.

41. Finally, it is likely that in order to improve their operational efficiency, some Thai universities might need to be merged with others to cope with a decreasing student population. Consideration might be given to mergers of administrative operations in order to reduce overhead costs, while universities keep their current names and locations. Beyond mergers, other joint operations, such as establishing cooperative networks or strategic partnerships, could be fostered. These can have the potential to contribute to efficiency savings through resource pooling, for instance by the means of sharing pedagogical staff, campus or research facilities. In Korea, the Yonsei University has partnered with the Pohang University of Science and Technology (POSTECH) and the Korea University, within the framework of the innovative "Open and Sharing Campus" model (Box 6).

\section{Box 6. The "Open and Sharing Campus" university model in Korea}

Similarly to Thailand and other Southeast Asian countries, Korean higher education institutions have been facing pressures to sustain their operations due to a contracting pool of students - a trend driven by the country's wider demographic challenges.

In order to address declining student cohort sizes, dwindling investment and challenges to keep up with the latest technological advancements, the Yonsei University in Seoul became party to the "Open and Sharing Campus" model in 2018. The model's objective is to allow universities to adapt to the challenges of a globalised 21 st century society by emphasising the concepts of openness, sharing and maximised resource utilisation. Within the framework of the model, the Yonsei University has concluded a partnership with the Pohang University of Science and Technology (POSTECH) in Pohang, and the Korea University, respectively.

Thanks to the cooperative arrangement, Yonsei University and POSTECH students are now able to attend courses and obtain credits from both institutions, take part in joint research projects or utilise the other institution's libraries and dorms. At the same time, Yonsei University students can apply to receive an ID card to access all resources and services of the Korea University's libraries located in two distinct locations.

Apart from expecting significant synergy effects, the Yonsei University equally aims to support innovation through its participation in the "Open and Sharing Campus". For instance, merging the clinical data from the Yonsei University's Severance Hospital with the engineering technological tools from POSTECH has the potential to result in novel research conclusions.

Source: The Yonsei Annals (2018), http://annals.yonsei.ac.kr/news/articleView.html?idxno=1927

42. The pressure on Thai HEls to maintain the sustainability of their operations is further intensified by evidence which shows that holding a tertiary degree has been well-rewarded in the Thai labour market. Despite the increased supply of tertiary educated workers until recently, the wage premium of university degrees, defined here as the ratio between the wage of workers with a university degree and that of workers with a lower secondary school diploma, has remained high.

43. As shown in Figure 11, in 2018 the average worker with a university degree earned a wage roughly 2.5 times higher than that of worker with a lower secondary degree. This figure shows that, despite a slight decrease from 2.8 in 2011, the demand for higher-level skills remains strong in relative terms. The figure also shows that the wage premiums to vocational and upper secondary degrees have remained stable and 
equalled 1.55 and 1.18 , respectively (meaning $55 \%$ and $18 \%$ higher salaries than secondary diplomas holders). In 2011, the average salary of workers in the lower educational attainment group was $47 \%$ lower than the salary of those with secondary education (wage premium was $53 \%$ ). In 2018 , the salary of workers in this group (primary education or below) rose and was then only $37 \%$ lower than the salary of workers with a lower secondary degree.

\section{Figure 11. Wage premiums of university degrees are strong}

Ratio of the average wage of workers relative the wage workers with a lower secondary diploma

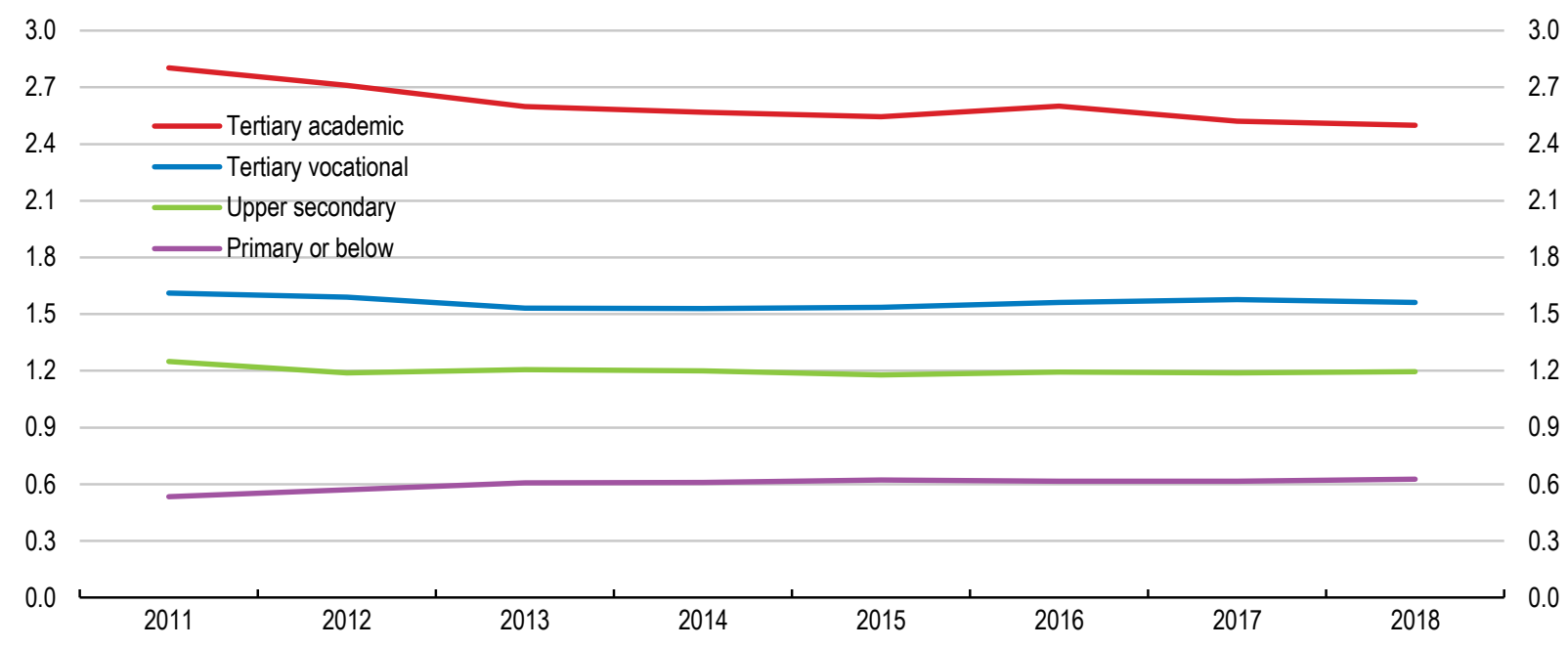

Note: Wage premium is the ratio of the average monthly wage for each educational attainment group with respect to the average wage of workers with a lower secondary school diploma (omitted reference group). The figure shows the regression coefficients of a Mincer-type regression of relative earnings on the educational level of workers, after controlling for age, gender, and other individual-level controls (Heckman, Lochner and Todd, 2006[38]).

Source: Thai National Statistical Office, Labour Force Survey (2011-2018) and OECD calculations

44. However, and despite a steady increase in the wages of university graduates over time, the wage benefit to university degrees is slightly weakening. In line with Tangtipongku (2015 $\left.{ }_{[39]}\right)$, data from the Thai Labour Force Survey shows that the wage of young workers with a university degree relative, for example, to the wage of workers with a lower secondary diploma, are somewhat lower than a decade ago. Changes in the wage premium to educational degrees reflect a mix of supply and demand factors in the labour market as well as structural factors in the economy. On balance, this evidence suggests that the rapid expansion of tertiary education in Thailand was not always matched with job opportunities for graduates (Paweenawat and Vechbanyongratana, 2015[40]).

45. In order to help students better understand the different education options and their returns in the labour market, Thailand should support the provision of high-quality career guidance services at the level of post-secondary and tertiary education. However, the 2018 PISA results show that fewer than one in ten Thai students receive advice from a dedicated school counsellor, with the burden of such counselling falling on teachers (OECD, 2019 $\left.9_{[41]}\right)$. Effective career guidance, provided by specialised, well-trained and resourced education counsellors, should support Thai students in choosing courses or qualifications that are in high demand in the labour market and suited to their interests and skills. Thailand needs to provide additional resources to aid those students approaching the end of their studies in a smooth transition to the labour market. 


\section{The ageing of tertiary educated workers has been slowed due to the influx of new graduates, especially in STEM fields}

46. The education and demographic trends discussed above are having a profound impact on Thailand's labour force. On one hand, as enrolment rates in higher levels of education increase and the educational attainment of the general population rises, the Thai workforce becomes increasingly more skilled. Over the last decade, the share of highly educated workers has increased significantly, while the share of less well-educated workers has been declining. As shown in the left panel of Figure 12, the share of workers with a university degree increased by $31 \%$ in the period 2011-2018. In contrast, the share of workers with primary education or less was $22 \%$ lower in 2018 than in 2011. The share of workers with lower and upper secondary degrees and with tertiary vocational degrees has also risen by $15 \%, 19 \%$ and $13 \%$ in the same period, respectively, although these rates are significantly lower than the rate at which university graduates are joining the workforce.

47. The second increasingly apparent trend is the increase in the age of workers. As discussed above, the workforce is ageing rapidly, as cohorts shrink and life expectancy soars. The right panel of Figure 12 shows the change in the average age of workers with different levels of education. The average age of workers with primary education or below increased from 45.8 to 49.3 years in 2011-2018. Similar figures can be observed for workers with secondary degrees. For instance, the average age of workers holding an upper secondary degree increased by roughly three years - from an average of 33.6 years in 2011 to 36.7 in 2018. The only exception to this trend is the group of workers with university degrees. Although this segment of the workforce has aged, the change has been much less pronounced. The average age of university-educated workers increased by less than one year in the period 2011-2018 due to significant influx of young graduates to the workforce, which has helped curb the ageing trend observed in other groups.

\section{Figure 12. Educated workforce is becoming older, except for workers with tertiary education}

Cumulative change in the number and average age of workers by educational attainment since 2011
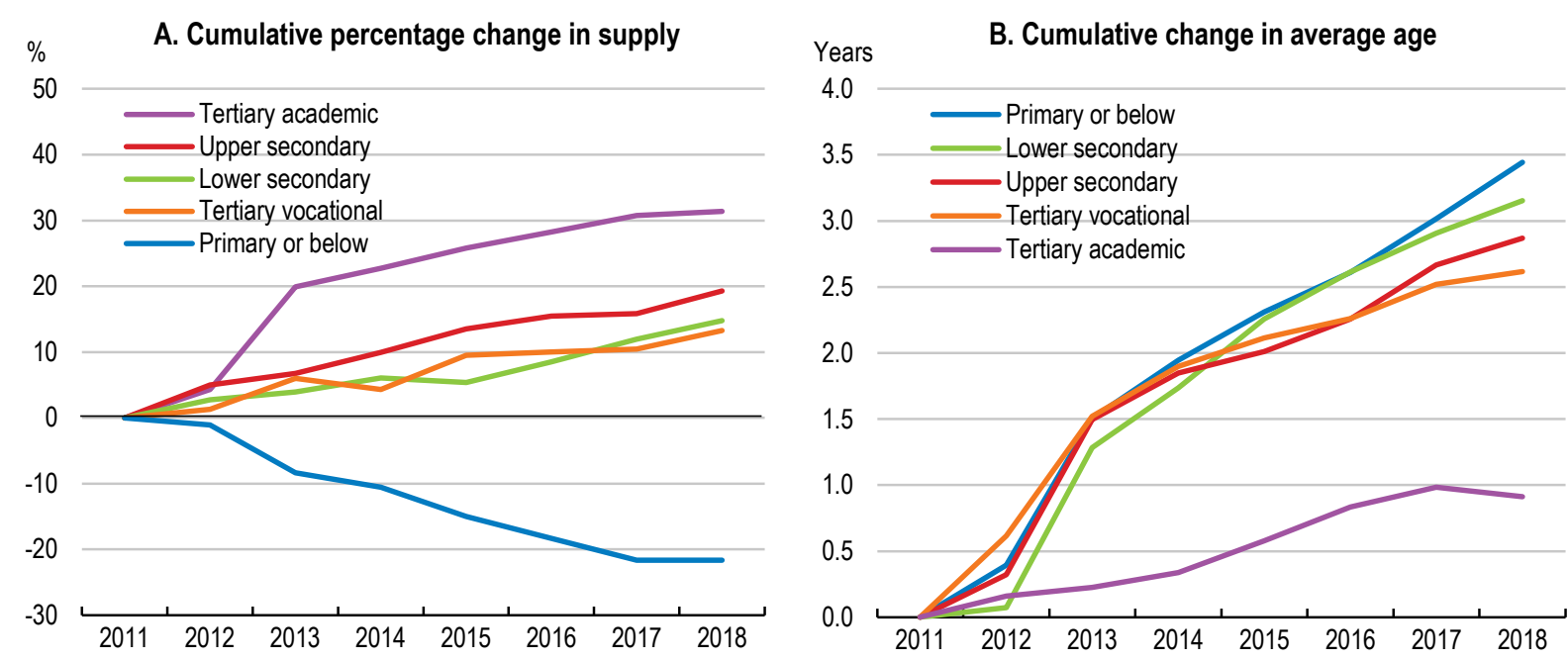

Source: Thai National Statistical Office, Labour Force Survey (2011-2018).

48. As thousands of students have obtained university degrees, the supply of young graduates (2434 years old) with specific skills has risen. Figure 13 shows the change in the number of workers with university degrees by field of study and age group between 2011 and 2018 . The figure shows that the number of workers with degrees in the "service" field - which includes personal, transport and security 
services - has increased by more than $110 \%$ between during the period, although they still account for less than $4 \%$ of the workforce. The Thai workforce has experienced a sharp influx of young university graduates holding degrees in the fields of engineering and manufacturing, social sciences and ICT, which have seen an increase of $70 \%, 41 \%$ and $39 \%$, respectively, during the 2011-2018 period. Such changes have also allowed the total supply of skills in these fields to increase in the workforce. For example, the total number of workers with university degree in the field of ICT (e.g. computing) and social sciences increased by $11 \%$ and $8 \%$, respectively.

\section{Figure 13. The supply of high-skilled workers in different STEM fields is increasing rapidly}

Percentage change in the number of workers with tertiary education (ISCED 6 and above) between 2011 and 2018 by field of study

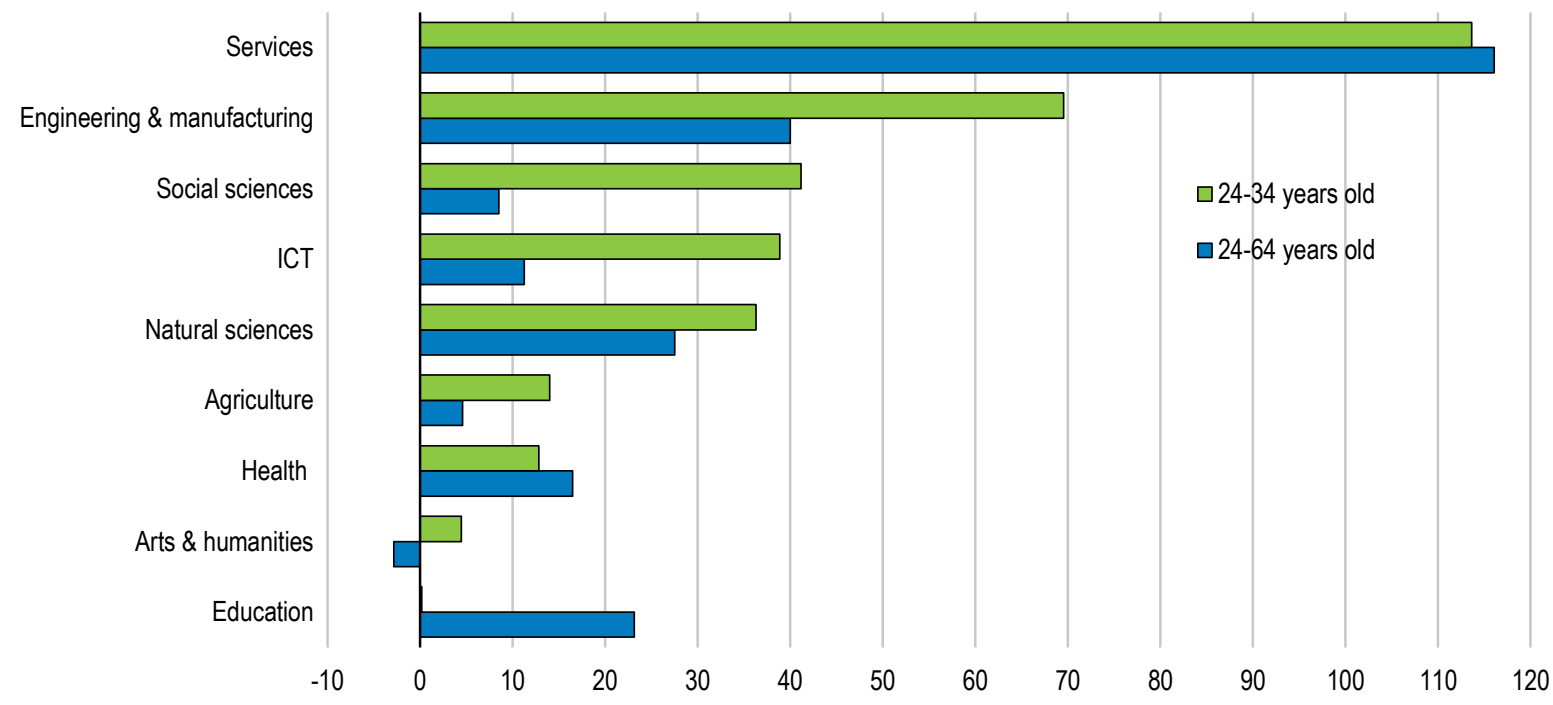

Source: Thai National Statistical Office, Labour Force Survey (2011-2018).

49. Figure 14 shows the share of workers in 2018 by specific major within the field. As shown in the figure, young Thai workers (24-34 years old) predominantly hold degrees with majors in business and administration, teaching, engineering and computing. The supply of skills in these fields - with the exception of teaching - is not only large in absolute terms, as measured by the number of graduates in the workforce, but it is also growing at a fast pace, as shown in Figure 12Error! Not a valid bookmark selfreference.. The increased supply of such skills is aligned with several initiatives focused on stimulating specific higher education choices, in the context of a government strategy to transform Thailand into a more skill- and technology-oriented economy. 
Figure 14. Young Thais workers predominantly hold degrees in business and administration

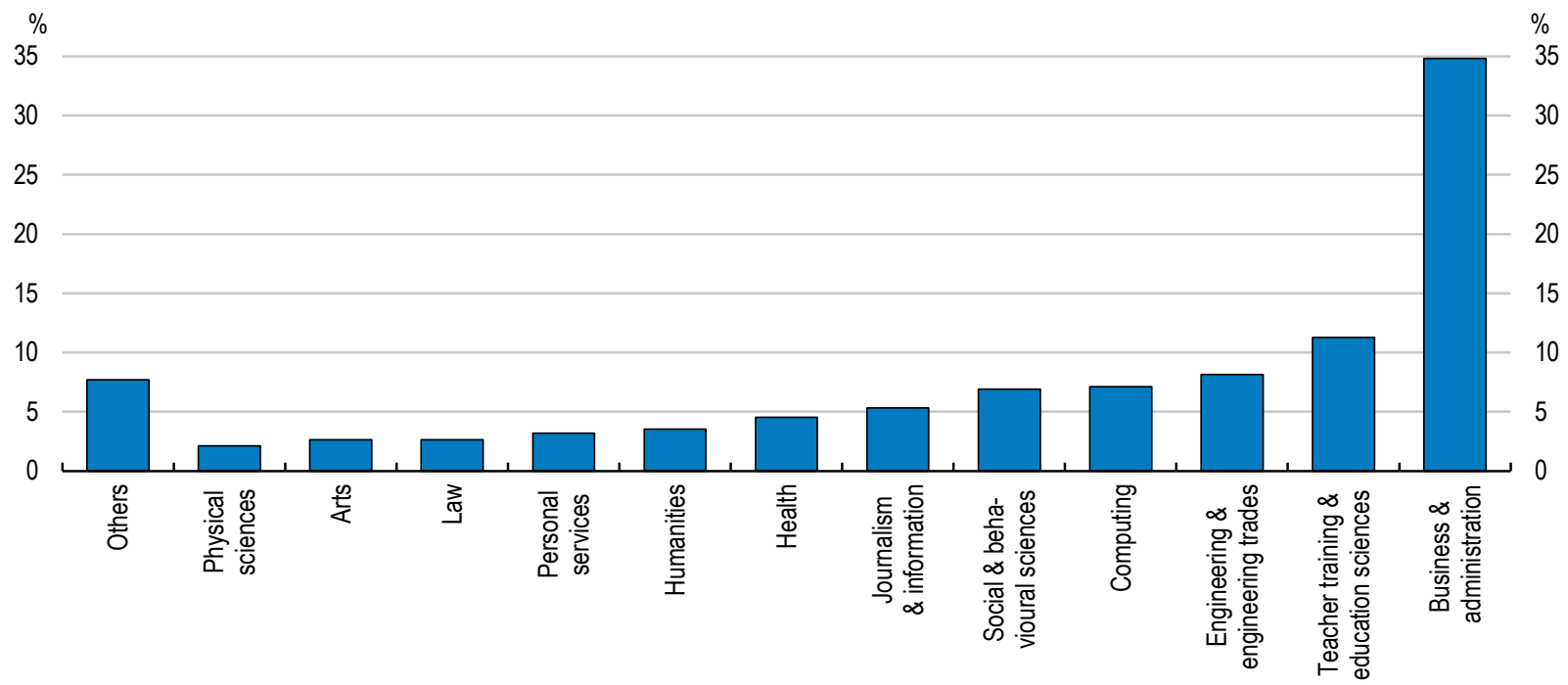

Source: Thai National Statistical Office, Labour Force Survey (2011-2018).

50. There has been a sustained push by the government to attract increasing numbers of students into STEM (Science, Technology, Engineering and Mathematics) and STI (Science, Technology and Innovation) fields. The need to attract more tertiary students to these fields has been highlighted at all levels of national development plans, including the 20-year National Strategy (particularly Strategy for National Competitiveness Enhancement and Strategy for Human Capital Development and Strengthening), the 12th National Economic and Social Development Plan and other national reform plans. These fields are also considered to be necessary in driving the country forward according to current government policies, such as Thailand 4.0, First S-curve/New S-curve or ten targeted industries, and the Eastern Economic Corridor (EEC).

51. To achieve the goal of boosting the supply of skills in the STEM and STI fields, Thailand has developed several important programmes and initiatives over the past years (see Box 7). The COVID-19 pandemic has allowed for exemplifying the importance of such strategy, with technological innovations crucial for the health sector developed by medical and engineering departments of several universities. While the Mahidol University has invented cheaper and faster COVID-19 tests (Bangkok Post, 2020[42]), engineers at the Kasetsart University have presented a prototype of a disinfection robot to be used to disinfect high risk areas without putting sanitation workers at risk (Pattaya Mail, 2020[43]). 


\section{Box 7. Thailand's initiatives supporting skills development in STEM/STI fields}

The "Engineering, Technology and Innovation Workforce Development" or "KOSEN" Project (โครงการพัฒนากำลังคนด้านวิศวกรรมศาสตร์ เทคโนโลยีและนวัตกรรม) aims to enhance national competitiveness and meet the new labour market demand through the development of practical engineers and technicians based on the Japanese unique engineering education called 'KOSEN'. The project is under partnership between the Thai Ministry of Education and Japan's National Institute of Technology and implemented by a joint KOSEN-KMITL (King Mongkut's Institute of Technology Ladkrabang) institute. Started in 2019, the project is expected to cost THB 4700 million (approx. USD 154.9 million) under its 13-year long plan. In addition, Thailand has also created scholarships to support the development of scientific knowledge, including the "STEM Workforce Scholarship" Project (โครงการพัฒนาศักยภาพบุคลากรเพื่อการวิจัยและพัฒนาสำหรับภาคอุตสาหกรรม), which aims at providing financial support to research work focusing on ten targeted industries, or the "Development and Promotion of Science and Technology Talents" Project (โครงการพัฒนาและสงเสริมผู้มีความสามารถพิเศษ ทางวิทยาศาสตร์ และเทคโนโลยี), which aims at offering scholarships for science education and organising science camps for Thai students.

The Ministry of Education, in particular the Office of the Basic Education Commission and the Institute for the Promotion of Teaching Science and Technology (IPST) has also developed programmes targeting students in the school system, such as the "STEM Education Implementation" Project (โครงการขับเคลื่อนการจัดการเรียนรู้สะเต็มศึกษา), which aims to promote STEM education in schools across the country through the provision of training, equipment, facilities, monitoring and evaluation, distance learning as well as other supportive activities. From 2016-2021, the project is expected to cost THB 541 million (approx. USD 17.8 million) covering 30717 schools by its end. Further, the IPST has facilitated the creation of the "National STEM Education Network", which includes a National Stem Education Centre, 13 Regional STEM Education Centres and STEM schools across the country with the aim of promoting the use of STEM education in daily and professional lives. Other efforts include the Junior Science Talent" "Al/Robotics for All" projects, among others.

52. Having invested resources to stimulate the supply of STEM skills in the labour force, the Thai government must also better coordinate these efforts to ensure that goals are achieved efficiently. To this aim, the government has established specific agencies and coordination bodies. For example, in mid-2019 the new Ministry of Higher Education, Science, Research and Innovation (MHESI) was created by merging the Office of Higher Education Commission with the Ministry of Science and Technology, and three committees have been established to promote STEM education in Thailand including the following: i) the Committee for STEM Learning Management, ii) Committee for STEM Curriculum Development, and iii) Committee for STEM Implementation in Schools. Looking to the future, the government's policy agenda includes new initiatives and projects, such as talent retention based on attractive wages/benefits, industryuniversity linkages through work-integrated learning, strengthening the postdoctoral and postgraduate research system, attracting foreign professionals and cross-sectoral talent mobility, among others.

\section{Further stimulating the demand for higher-level skills to achieve full potential of Thailand 4.0}

53. Previous sections have shown that there are strong reasons to support Thailand's effort to increase the educational attainment of its population and to promote the equal acquisition of higher-level skills among younger generations. Boosting people's skills not only pays off in the labour market, but it is also a necessary pre-condition to paving the way for Thailand's transition towards a technology-driven and an industry-oriented economy. Moreover, recent research has shown that common foundations and linkages exist between slowing productivity gains and rising or persisting inequalities (OECD, 2018[44]). For this 
reason, in order to move up the value-added ladder, it is important for Thailand to reduce existing inequalities, increase the educational attainment and boost the supply of skills that are commonly needed in advanced and technology-driven economies. At the same time, these skills policies also need to be paired with policies that stimulate the demand for such skills in the labour market, such as boosting trade and the inflow of foreign direct investment (FDI) by removing barriers to entry for firms, supporting entrepreneurship and SMEs, and providing government support for innovation.

54. In order to help create demand for highly skilled workers, Thailand should intensify efforts to boost technology adoption levels. The country has already laid the right foundations by defining the objective of increasing R\&D expenditure to $4 \%$ of GDP by 2032 , as part of Thailand 4.0 . In the context of an increasing number of tertiary educated graduates entering the labour market, Thailand should direct its focus towards the support of programmes and initiatives, which foster the development of technological advances as well as their diffusion within Thai enterprises. At the same time, support measures helping promising start-ups to scale up and adopt new technologies similarly hold potential to help bring the supply and demand for higher-level skills into balance in the long term (OECD, 2019 $\left.{ }_{[45]}\right)$.

55. With potential to foster technology transfer and important knowledge spill-overs which had been importantly aiding to motivate the demand for higher-level skills, Thailand should maintain its focus on improving its FDI regime while advancing with further trade liberalisation. OECD $\left(2019_{[46]}\right)$ shows that FDI restrictions are associated with a lower stock of FDI per capita. Nonetheless, Thailand's regulatory framework governing the flows of inward FDI remains comparatively restrictive. On the OECD FDI Regulatory Restrictiveness Index, Thailand's scores of 0.291 ( $0=$ open, $1=$ closed) is above both the OECD and ASEAN-10 averages, while only the Philippines, Myanmar and Indonesia exhibit more restrictive FDI regimes (OECD, 2018[47]). Thailand could similarly make further progress with respect to trade liberalisation and facilitation. The OECD Services Trade Restrictiveness Index (STRI), which quantifies barriers to services trade, suggests that Thailand's regulatory framework should be less restrictive, as the current regulations lead to international trade impediments (OECD, 2018 $\left.8_{[47]}\right)$, and thus suppress opportunities to develop more intensive demand for higher-levels of skills in the country.

56. Further opportunities for FDI could also be created by universities assuming a stronger role in supporting entrepreneurship. In this context, it is positive that Thailand has put in efforts to foster collaboration between academic institutions and entrepreneurs. For example, in the Eastern Economic Corridor (EEC) area, they adjust the courses provided to be in line with "Cooperative and Work-Integrated Education", where employers and institutions work together in structuring practical and theoretical parts of the curricula. However, more could be done through the creation of networks of universities and the private sector to promote SMEs and start-ups. While some universities are already offering training, mentoring, and facilitating access to credit, it is necessary to integrate and align all efforts to support local business and innovation to build strong linkages between universities and the start-up private sector. This could be achieved by creating physical spaces where academics can interact with private sector actors, joint financing from the private and the public sectors, international involvement, and creating other incentives to support the transfer of knowledge between science and industry. Further, all supporting universities and institutes could establish a network to share informational resources and strategies. Alternatively, establishing an institute for higher education institutions and SMEs that coordinates the efforts to stimulate entrepreneurship at a regional level could be another strategy. Box 8 presents an example of effectively engaging a variety of stakeholders, in relation to VET and adult education in Germany. 


\section{Box 8. Germany's Alliance for Initial and Further Training}

In 2014, the Alliance for Initial and Further Training was established in Germany. The Alliance is both a document signed by the various partners and a body or discussion forum established to accompany and supervise the implementation of skills policies and initiatives agreed upon. Within the Alliance's structures, unions are formally represented by the German Trade Union Confederation (Deutscher Gewerkschaftsbund, $D G B$ ), which co-ordinates directly with major unions, such as the IG Metall (Industriegewerkschaft Metall), ver.di (Vereinte Dienstleistungsgewerkschaft), IG BCE (Industriegewerkschaft Bergbau, Chemie, Energie) and IG BAU (Industriegewerkschaft Bauen-AgrarUmwelt) who are involved as member organisations of the DGB. Moreover, the representation of German Länder governments is also assured. In addition to the Standing Conference of the Ministers of Education and Cultural Affairs of the Länder (KMK) as representative of the Länder education ministries, the Alliance includes a representative of the conference of Länder ministries for economic affairs and the conference of labour and social affairs ministries. The Federal Employment Agency (Bundesagentur für Arbeit, BA) is also an official partner. Other relevant partners include representatives from the various employer organisations and government departments. The Alliance thus encompasses an impressive range of stakeholders, effectively bringing together different government departments (education, business and labour), levels of government and stakeholders.

One of the most prominent topics that the Alliance deals with is ensuring a sufficient supply of training places for the youth. More specifically, the business partners in the Alliance have committed to providing 20000 "additional" (rather than simply "new") apprenticeship training slots per year from 2015, as well as 500000 internship places for students and pupils. Furthermore, the Alliance partners have re-stated their commitment to provide a training opportunity to every applicant, preferably in firm-based training. The business partners in the Alliance commit to providing three offers for firm-based apprenticeship training to youth who did not manage to secure a training place by 30 September (the official starting date of the training cycle), as long as the youth are regionally mobile.

Another notable policy instrument of the Alliance agreement is embodied by the "assisted apprenticeship" (assistierte Ausbildung), directed at improving the integration of disadvantaged youth into the training system. Before the Alliance agreement was enacted there were numerous instruments available to support the integration of youth who struggled to find a regular apprenticeship training slot in the open market. The assisted apprenticeship scheme, however, addresses an important gap in supporting measures by providing direct support, in the form of dedicated personnel with specialised social and pedagogical skills, for training firms that hire disadvantaged youth on a regular apprenticeship. The support is available for the entire training period. As youth are employed as regular apprentices within firms (rather than visiting out-of-firm training courses, for instance), their chances of securing employment after training is increased. The instrument of assisted apprenticeship is broadly supported by unions, employers and state actors. In the Alliance agreement, the government (i.e. the Federal Employment Agency) committed to financing 10000 places for assisted apprenticeships in the first year of the Alliance period, and the signatories agreed that the instrument should become a regular element in the statutory toolbox of labour and training market policies soon thereafter.

Source: OECD (2020), Strengthening the Governance of Skills Systems: Lessons from Six OECD Countries, OECD Skills Studies, OECD Publishing, Paris, https://doi.org/10.1787/3a4bb6ea-en.

57. Entrepreneurial education could also be integrated with higher education, and in particular technical education. This could be done by training all staff and preparing resources in institutions of higher education such that local schools could offer courses that provide students with an entrepreneurial mindset, motivation, and technical skills in parallel. 


\section{The state of skills imbalances in Thailand}

58. In light of structural changes that impact the demand for and the supply of skills, it is becoming increasingly important that the skills of workers are effectively aligned with the needs of the labour market. Imbalances between the supply and demand for skills can emerge in the form of 'skill shortages' - when adequate skills are hard-to-find in the current labour market - or in the form of 'skill surpluses' - when certain skills are in excess in the labour market relative to the demand (OECD, 2017[48]). In addition, imbalances also comprise skill mismatch when a workers' skills or qualifications exceed or fall short of those required for the job under current market conditions (OECD, 2017[48]; Shah and Burke, 2005[49]). Mismatch can be measured along different dimensions, including skills, qualifications and field of study. Imbalances have been found to have negative consequences for individuals, firms and the economy more broadly, through lower productivity, wages and job satisfaction.

59. The OECD Skills for Jobs indicators measure skills imbalances in an internationally comparable way, see Box 9 for details on the methodology. As Figure 15 shows, the Thai labour market is facing substantial shortages in a range of occupations and industries. It is important to note that the data refers to the period before the COVID-19 crisis, and therefore reflects structural imbalances that are unrelated to this recent labour market shock. The largest shortages are found in professional occupations and clerical support occupations, but also in more technical occupations, like crafts and related trades workers and plant and machine operators and assemblers. When looking at the more detailed occupational level (not shown here), the occupations with the strongest shortages are: i) Health Professionals, ii) Legal, Social, Cultural and Related Associate Professionals, iii) Food Preparation Assistants, iv) Business and Administration Professionals, and v) Metal, Machinery and Related Trades Workers. This shows that shortages can be found across the skills spectrum. Surpluses, on the other hand, are mainly found for skilled agricultural workers. The latter is consistent with the long-term decline in the importance of agriculture in the total labour market. Certain management occupations, including Hospitality, Retail and Other Services Managers, and Chief Executives, Senior Officials and Legislators, are also facing substantial surpluses. A similar pattern of shortages and surpluses can be seen at the industry level (Panel $B$ ), with the largest shortages observed in the education sector, and large surpluses in the agricultural sector. These imbalances could be the results of several factors, including an inadequate supply (e.g. few university graduates with specialisation in health care, see Figure 15), skills of graduates not matching employers' requirements, and the attractiveness of working conditions. 


\section{Figure 15. Several occupations and industries are facing substantial shortages}

Shortages (+) and surplus (-) intensity, by occupation and industry
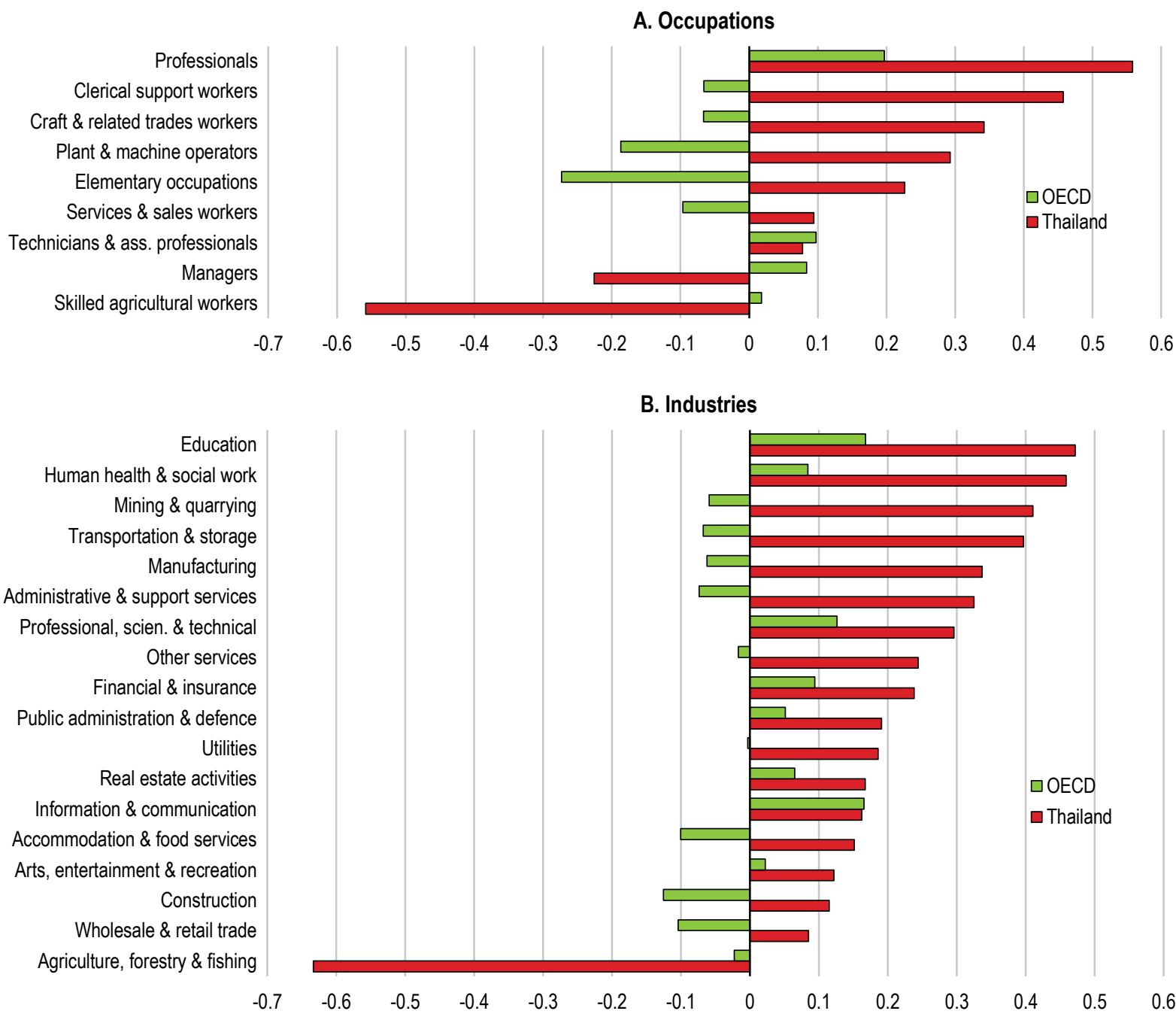

Note: Values range between -2.5 (maximum possible surplus) and +2.5 (maximum possible shortage). The Thai results refer to 2018 , the OECD results to the latest available year in each country. See Box 2.1 for details on the methodology.

Source: OECD, Skills for Jobs Database using Thai Labour Force Survey data (2011-2018).

60. The shortages observed at the occupational level translate into shortages of cognitive skills, such as mathematical reasoning, writing and reading comprehension, but also certain social skills, like service orientation, and technical skills (e.g. programming and technology design). The knowledge areas found to be most in shortage are 'computers and electronics', 'clerical knowledge' and 'customer and personal service'. As Thailand continues to be exposed to global mega-trends, such as population ageing, globalisation and automation, shortages of high-level cognitive skills and social skills are likely to become even more pronounced, as is the case in many OECD countries today. Occupations that have a relatively low probability of change due to automation, which are generally the ones requiring high-level cognitive skills and/or social skills, are already more likely to be in shortage in many OECD countries. Moreover, OECD countries that have seen the strongest increase in their old-age dependency ratio are experiencing stronger shortages in health and personal care related jobs, which require strong social skills (OECD, 2017[50]). Moreover, in the United States, employment growth has been strongest in jobs requiring high 
levels of both cognitive skills and social skills (Deming, 2017[51]). In OECD countries, the occupations that combine high cognitive skills requirements with social skill requirements are the ones that are facing the strongest shortages $($ OECD, 2017[50]). Many countries are already facing shortages in ICT-related skills, and these could be expected to increase as technology adoption spreads across all types of occupations. Moreover, the need for strong digital skills was highlighted during the COVID-19 crisis, with many employers adopting telework and digital tools becoming essential also in daily life.

61. The recent COVID-19 outbreak exacerbated already existing shortages in the Thai healthcare sector. At the height of the COVID-19 healthcare crisis, the Thailand Nursing and Midwifery Council called for 400 experienced nurses to take care of the growing number of patients. Other sectors are also facing shortages linked to the COVID-19 crisis. This is the case for example for the agricultural sector, which employs a large number of migrant workers (and was facing excess supply of skills before the crisis). With the Covid-19 outbreak and ensuing border closures in Thailand, many migrant workers left Thailand, resulting in labour shortages in the agricultural sector. Other sectors are faced with excess supply of workers due to falling demand for goods and services. This is particularly the case for the tourism and hospitality sector in Thailand, which has been heavily impacted by lockdowns and the banned entry into Thailand by foreigners. The sector accounts for $9 \%$ of employment in Thailand, with many of the workers in this sector at risk of being out of work for extended periods (ILO, 2020 $0_{[52]}$ ). The University of the Thai Chamber of Commerce estimates that up to 6 million people employed in the tourism sector and related sectors will end up unemployed, and the number could even rise to 10 million if the pandemic does not subside by the end of June 2020 (University of the Thai Chamber of Commerce, 2020[53]).

62. Finally, in addition to substantial shortages and surpluses, the Skills for Jobs data also show that the Thai labour market has a significant share of workers who are mismatched in terms of qualification level and/or field. In 2018, $7.8 \%$ of workers were under-qualified for their occupation, and an additional $34 \%$ were over-qualified (Figure 16). This is quite different from the qualification mismatch pattern observed in OECD countries, where on average $18.6 \%$ of workers are under-qualified and $17.1 \%$ overqualified. However, similar patterns as the one observed in Thailand can be found in Turkey, Peru and Brazil. As discussed above, the presence of over-qualification in the Thai workforce is consistent with the fact that employment growth in Thailand in recent decades has been mainly concentrated in low-skill occupations (World Bank, 2016[54]). These findings are in line with the analysis carried out by the Bank of Thailand (เสาวณี จันทะพงษ์ and นางสาวกานต์ชนิต เลิศเพียรธรรม (Chantapong, Saovanee and Kanchanit Lertpienthum), 2018[55]), which shows that the demand in the Thai labour market is strongest for workers with lower vocational certificates and those with a secondary education or lower level degree, while the supply is highest for individuals with a tertiary education degree. Under-qualification, on the other hand, might reflect that employers have difficulties finding workers with the right qualification level and resort to hiring under-qualified workers. It should be noted, however, that under-qualified workers are not necessarily under-skilled for their jobs, as often workers acquire skills informally. A system of recognition of prior learning can help to certify these skills and make them more visible to employers. When looking at the field of study rather than the level of education, $37 \%$ of Thai workers are mismatched, compared to $32 \%$ across OECD countries. 
Figure 16. Many workers are employed in occupation that do not match their education

Share of workers mismatched by qualification level or field, 2018

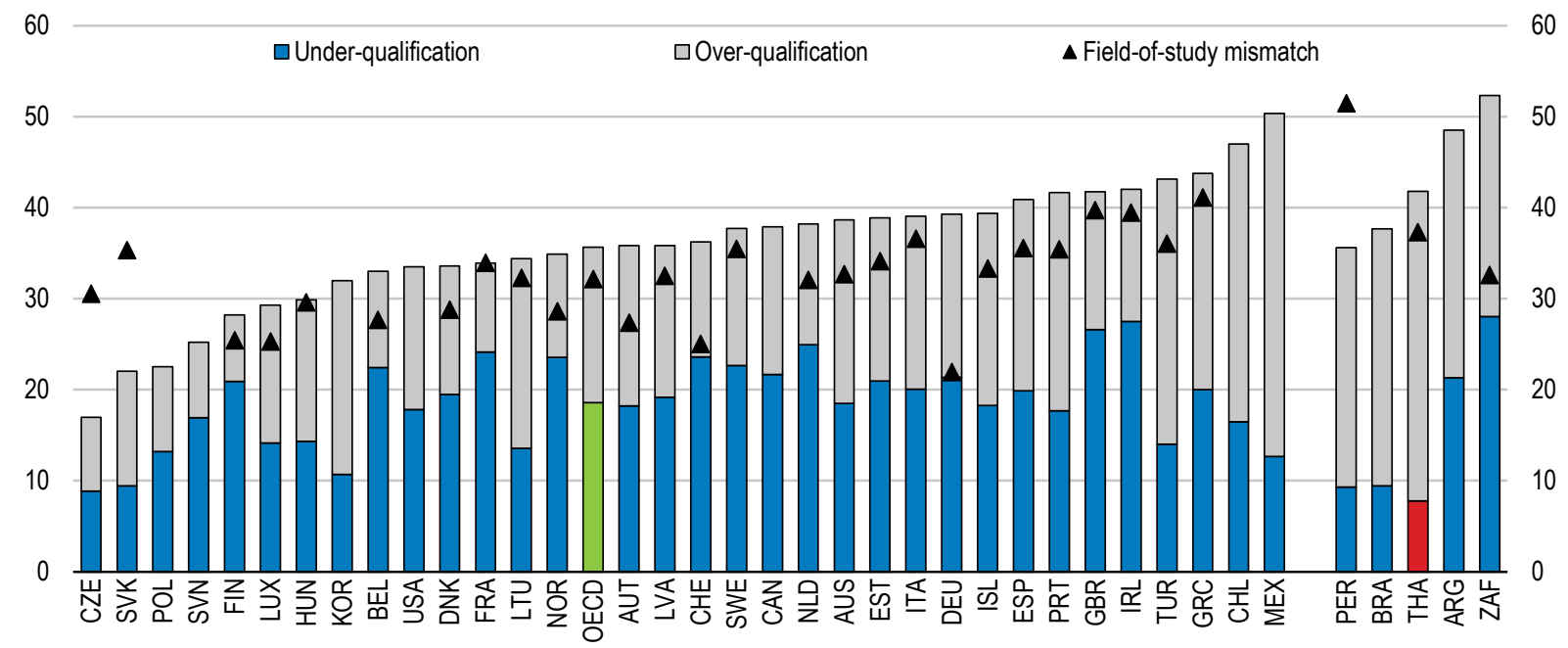

Note: Workers are mismatched by qualification level when their highest obtained qualification (primary education or below, lower-secondary education, upper-secondary and post-secondary non-tertiary education, or tertiary education) is higher or lower than the one most commonly observed among workers in the occupation. Workers are mismatched by field of study when the field of their highest obtained qualification does not correspond to the field of their occupation.

Source: OECD Skills for Jobs Database.

63. Over-qualification is most common in Thailand among sales and service workers (59\%) and Plant \& Machine Operators and Assemblers (50\%). The industries with the largest shares of overqualified workers are the Wholesale and Retail industry (48\%) and the Accommodation and Food Services industry $(48 \%)$. By contrast, under-qualification is most common among Managers (35.5\%) and clerical support workers (35\%), and in the Arts, entertainment \& recreation industry (20\%). Mismatch by qualification level is very uncommon in some occupations and industries: Only $7 \%$ of professionals and $11 \%$ of workers in the education sector are mismatched by qualification level. Field-of-study mismatch is especially common among those who specialised in arts and humanities ( $83 \%$ not working in their field) or in ICT ( $87 \%)$, while it is least common among graduates in the area of health and welfare (14\%). Individuals might decide to work in a field that is unrelated to the one they studied for several reasons, including a lack of job opportunities in their own field and more attractive working conditions in other fields. 


\section{Box 9. The OECD Skills for Jobs Indicators}

\section{Shortages and surpluses}

To analyse the degree of skill shortages and surpluses in countries' labour markets, the Skills for Jobs methodology uses five sub-indicators to extract signals of occupational shortage/surplus pressure: i) employment growth, ii) hours worked growth, iii) unemployment rate ${ }^{a}$, iv) change in the share of underqualified workers, and v) hourly wage growth. For each occupation, the long-run trends of these indicators are measured relative to the economy-wide trends. The five indicators are aggregated into a final occupational shortage index.

To get an understanding of the actual skills that are in shortage or surplus (rather than the occupations), the occupational shortage indicator is translated into a skill need indicator by using information on skills requirements by occupation (from the United States Department of Labor's O*NET database) ) $^{\mathrm{b}}$. The final skills needs indicator shows the degree of shortage or surplus for a wide range of skills, abilities and knowledge types.

\section{Qualification and field-of-study mismatch}

Qualification and field-of-study mismatch measure the misalignment between a workers' occupation and his/her qualification level and field-of-study, respectively. Workers are said to be underqualified when their highest educational attainment is below the usually observed qualification level in the worker's occupation. In the opposite case, when a worker's qualification level is above the standard qualification level in his/her occupation, this worker is overqualified. Similarly, a worker is mismatched in terms of field-of-study when the field-of-study of his/her highest attained qualification does not match with the field generally required in the worker's occupation.

a The Thai Skills for Jobs analysis uses data from the Thai Labour Force Survey (2011-2018), and results for the occupational shortage index are based on four sub-indicators (as variations in the unemployment rate by occupation are too limited to extract meaningful signals about shortage and surplus).

$\mathrm{b}$ The assumption is made that skill requirements by occupations are the same in Thailand as in the United States. While the cross-country validity of $\mathrm{O}^{*} \mathrm{NET}$ has been confirmed for a range of OECD countries, some concerns have been raised regarding the use of O*NET for lower-income countries.

Source: Adapted from OECD (2017b), Getting Skills Right: Skills for Jobs Indicators, https://dx.doi.org/10.1787/9789264277878-en

64. Many countries are using similar types of analyses to understand the skill needs in their labour market. In Malaysia, for example, a Critical Occupations list is established every year, identifying the occupations that are facing talent shortages in the economy. To assess these shortages, quantitative information (e.g. employment growth, wage growth and vacancy rate) is used, combined with input from employers. The list is used in Malaysia to inform migration policy and to review programmes in higher education (OECD, 2019 $\left.{ }_{[56]}\right)$. In Thailand, a data-driven analysis of skill needs does not seem to be carried out in a regular and holistic way. Several analyses have been done for specific sectors or regions (e.g. for the new S-curve industries and for the Eastern Economic Corridor). Every few years, the National Statistics office carries out an employer survey to understand labour demand (the latest one dates back to 2013). Finally, on a monthly basis, information is provided about vacancies and jobs fulfilled by industry, occupation and province. Taking stock of these exercises and facilitating knowledge sharing between the actors involved, could facilitate better collection and use of skill needs information in Thailand. 


\section{Reducing skills imbalances by promoting adult learning}

65. As discussed above, a number of people in Thailand work in occupations that do not match their education and skills. In order to prevent such imbalances from arising in the first place, strengthening the responsiveness of the education system to the labour market needs is a crucial first step. Information on labour market and skills needs, which often rely on effective skills anticipation and assessment (SAA) exercises, should therefore be extensively disseminated to future graduates, and supported by robust career guidance services. At the same time, it is important that the needs of the labour market are translated into the contents of curricula and guidelines for work-based learning (WBL), especially at the level of VET schools. Further, an important component of aligning the educational offer with the labour market requirements is related to government incentives provided to educational institutions. These could take the form of regulation (e.g. defining the conditions for accrediting specific courses) or financing arrangements (conditioning the provision of funding on performance indicators related to graduates' employability or wages).

66. Still, many workers, who already left education, are at an imminent risk of being affected by structural changes. In addition, due to the recent coronavirus pandemic, there may be large and rapid shifts in the demand for labour across sectors than ever, while more workers may be displaced. On the other hand, the demand for higher-level skills may have increased (and might continue to do so) even in sectors that have traditionally relied on low-skilled labour, such as food services, retail, and administrative work (OECD, 2020[57]). All these trends would require more opportunities for fast and smooth up-skilling and re-skilling of the population affected by these changes. Adult learning systems therefore can play a key role in responding to changing skill needs and addressing or preventing skills imbalances. Yet, this is also where the challenge lies. In Thailand, as well as in many other countries, adult learning systems often lack focused attention and resources, putting in doubt their readiness to address future skill challenges.

\section{Promoting participation in adult learning}

67. Adult learning systems are essential to help adults maintain and upgrade their skills to harness the benefits that the abovementioned megatrends will bring. However, available estimates for OECD countries show that, in most countries, those who need training the most have limited or no access to training (OECD, $\left.2019_{[6]}\right)$. Adult learning systems often lack focused attention and resources to ensure the training is accessible and aligned with the needs of the labour market, putting in doubt their readiness to address future skill challenges.

68. Evidence suggests that adults in Thailand have comparatively limited access to training opportunities. According to the World Bank Enterprise Survey, which contains information from over a thousand registered firms with at least five employees, only $18 \%$ of employers provided organised training activities to their workers between 2015 and 2016 (Figure 17). This share is much lower than the average in upper-middle income countries (36\%) and East Asia and the Pacific (37.7\%). 


\section{Figure 17. Relatively few firms train workers in Thailand}

\section{Percentage of manufacturing firms offering formal training}

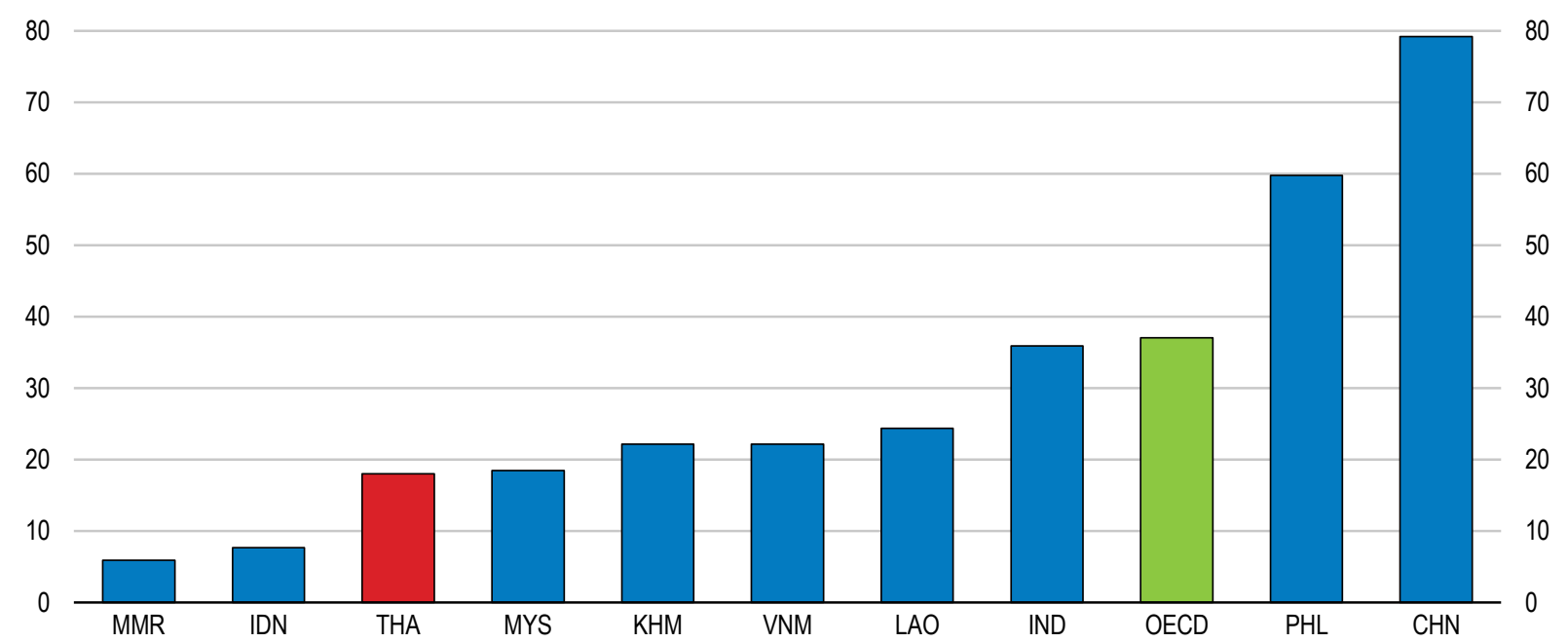

Note: Data refer to 2013 for China, 2014 for India, 2015 for Indonesia, Malaysia, Philippines and Viet Nam, to 2016 for Cambodia, Myanmar and Thailand, 2018 for Lao P.D.R. and to 2010-19 for the OECD average of 15 available countries. Only training that has a structured and defined curriculum (e.g. classroom work, seminars, lectures, workshops, and audio-visual presentations and demonstrations) is included.

Source: World Bank, Enterprise Surveys, http://www.enterprisesurveys.org.

69. Adult learning systems must provide sufficient and equal opportunities for participation in training to all adults, including vulnerable groups such as women, older workers and low-skilled workers. Building capacity of enterprises, both large and small, is essential to provide sufficient training opportunities to all workers. In Thailand, the Skill Development Promotion Act is in place to promote training at the workplace. According to the law, enterprises hiring more than 100 employees are required to arrange training programmes to at least $50 \%$ of the employees, on the annual basis. However, rather limited workers can benefit from this law, as a large share of workers are in SMEs, with less than 100 employees.

70. Across OECD countries $76 \%$ of companies with more than ten employees provide training for their staff $($ OECD, 2019[58]). Several OECD countries adopted measures that include a mix of hands-on consultancy and financial incentives to develop the capacity of companies to provide training. For example in Korea, building the capacity of SMEs to develop skills of their staff is the declared goal of the Korean Subsidies for Learning Organisations. Employers can access a set of complementary subsidies to hire external consultants to analyse the company's training needs, to provide training to CEOs and staff responsible for learning activities, to take part in peer-learning activities and to share their experience of building a learning organisation (OECD, 2019[58]).

71. On the other hand, in Thailand as well as in many OECD countries, evidence suggests that a majority of adults do not participate in training due to the high obstacles they face. According to Skills Development Survey data (2019) from the National Statistical Office of Thailand, about $91.6 \%$ of adults responded that they do not desire to participate in adult learning. The share of people who do not desire to participate seems to increase along with age. It is particularly high among adults over 60 years old $(97.3 \%)$ and adults between 55 and 59 (92.3\%), while it is relatively lower for younger adults between 15 and $24(88 \%)$. On the other hand, the share is also higher among people with low education (95\%) than with secondary education or higher (90\%).

72. Adults might not want to participate in training for a variety of reasons, some related to a lack of motivation, others to practical barriers, such as financial and time constraints. The main barriers to participation in training for Thai adults include lack of time (44\%), need to take a rest (15\%), and too old 
for training (14\%) (Figure 18). This could imply that many adults feel that their family or work related burdens are too great to schedule extra training, with long working hours. As pointed out by OECD (2019), to overcome this barrier, adult learning programmes should ideally be flexible (OECD, 2019[59]; OECD, 2019[6]; OECD, 2019 $\left.{ }_{[45]}\right)$. Modular approaches are especially helpful in providing adult learners with greater flexibility on their learning path. They allow adult learners to focus on developing the skills they currently lack, complete self-contained learning modules on these skills and combine these modules to eventually gain a full (formal) qualification (OECD, 2019[59]). Research suggests that such provision can broaden access to formal qualifications, in particular for disadvantaged groups (Kis and Windisch, 2018[60]).

\section{Figure 18. Adults face multiple barriers to participating in training}

Reasons for not desiring to participate in job-related adult learning, 2019

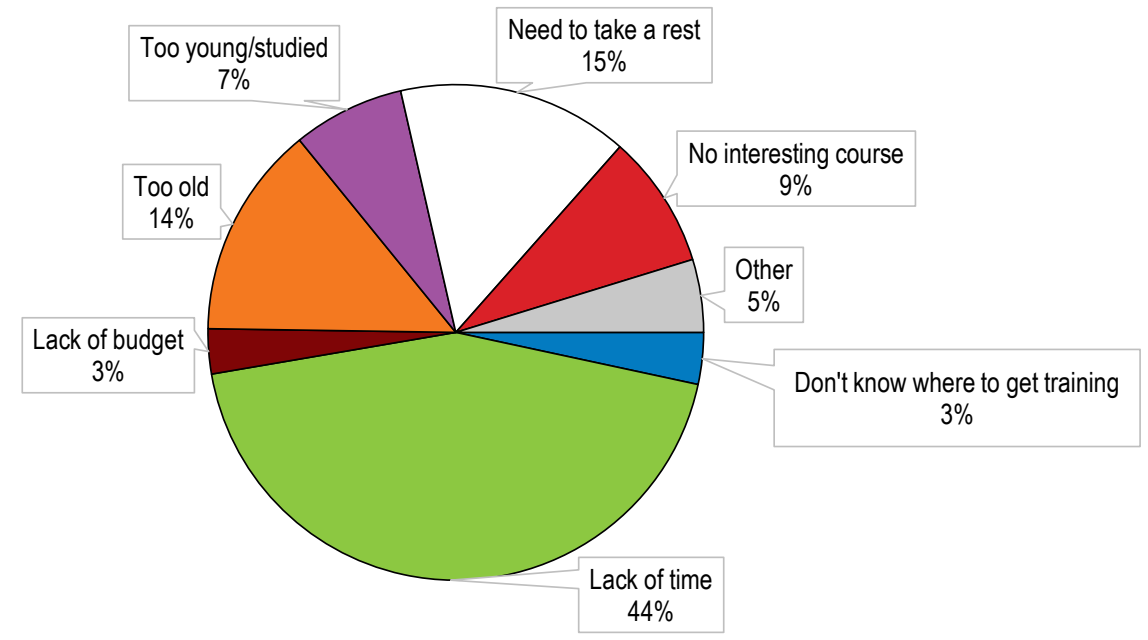

Note: Other reasons include reasons due to sickness, handicapped, and unknown reasons, among others.

Source: Thai National Statistical Office, Skills Development Survey (2019).

73. In Thailand, recognition of credits and learning outcomes is possible through partial qualifications, professional certifications, modularisation of programmes, short courses and part-time courses. For example, the Bangkok Metropolitan Administration's (BMA) Vocational Training Center provides a number of job training courses, including part-time and weekend courses. Chiva-Som International Academy offers several short-term courses of a week to three months, which could lead to accredited certificate to become high quality spa professionals after completion. In addition, Massive Open Online Courses (Thai-MOOCs) has been developed as an open platform for education and learning under the concept of "lifelong learning space for all". Thai-MOOCs can be transferred to accredited certificates as long as courses meet the requirements of the Thailand Professional Qualification Institute. The online training opportunities could play a particularly important role to ensure people continue to have access to timely and relevant training even during the COVID-19 crisis, when face-to-face training is not possible. The availability of existing online training solutions has enabled many countries to continue the provision of training measures (on a selected set of skills that is possible to teach online) during the pandemic with a minimal investment (OECD, 2020[57]).

74. Many OECD countries offer some or several forms of flexible learning provision. In Mexico, participants in the Model for Life and Work programme (Modelo Educación para la Vida y el Trabajo, MEVyT), which provides learning opportunities for youth and adults to catch up on primary and secondary education, can combine different modules that cover a variety of topics. Some of the modules are delivered on an online platform (UNESCO Institute for Lifelong Learning, 2016[61]). In Denmark, for example, 
individuals working towards a vocational qualification in Labour Market Training Centres (Arbejdsmarkedsuddannelse) can choose from a wide range of vocational training courses but also tap into subjects provided by the general education system. This allows learners to tailor their education and training programme based on their individual needs (Richard Desjardins, 2017[62]).

75. Flexibility is also important when it comes to access to training policies and coverage of training rights. There is evidence to suggest that the share of non-standard workers (e.g. temporary, own-account, and platform workers) has risen in a number of countries, including Thailand, and many workers face more fragmented careers than before, with more frequent moves in and out of work as well as between different employment forms (OECD, 2019[6]; ILO, 2016[63]). These trends have raised concerns amongst policy makers that many of these workers are not adequately covered by labour market rights, including training rights. One adult learning policy that could improve access to adult learning for all workers, including nonstandard workers, is an individual learning scheme (Box 10). To reach its potential, however, the scheme needs to be carefully designed, making sure of its simplicity, adequate and predictable funding, greater generosity for those in need, provision of effective information, advice and guidance, a guarantee of access to quality training, and explicit account of the links with employer-provided training, among others (OECD, 2019[64]).

\section{Box 10. Individual Learning Account}

\section{Tying training rights to the individual rather than to the job}

Individual Learning Accounts are virtual individual accounts in which training rights are accumulated over time. They are virtual in the sense that resources are only mobilised if training is actually undertaken.

The only genuine example of an Individual Learning Account is the French Compte Personnel de Formation (CPF), which is currently undergoing significant reform. In the CPF, training rights are accumulated over time. Initially, these rights were measured in of hours of training but, since January 2019, the unit of measure has become monetary (Euros). Training rights are accumulated at two different rates, depending on the initial level of education of the individual, with low-educated individuals accumulating more training rights. The CPF was initially available to employees and jobseekers only. Since January 2018, the self-employed are also covered, but in practice they have not yet started to use the scheme.

For jobseekers and employees, the scheme is financed through a compulsory training levy on firms equivalent to $0.2 \%$ of gross wages. Self-employed contribute $0.2 \%$ of turnover to a training fund. Up until December 2018, training funds - also financed by the training levy - could complement funding of training undertaken by employees via the CPF. Pôle emploi (the French public employment service) and the regions can also complement funding for training undertaken by jobseekers.

Credits can be used to pay for training fees of programmes that are required to deliver a certificate (certification), i.e. be registered at the Répertoire national des certifications professionnelles (RNCP) or at the répertoire spécifique. Skill assessments (bilan de compétences), actions for skill recognition, driving licenses, and training for business creation can also be covered.

Source: OECD 2019, "Individual Learning Accounts: Design is key for success", Policy Brief on the Future of Work, OECD, Paris

76. Another major obstacle to participation in adult learning in Thailand is the concern that many adults are too old for it. In most OECD countries, older adults participate less in training than prime age adults. Eurofound (2016) finds that older workers in Europe have limited access to training due to inadequate training provisions and fewer prospects for career advancement. Many employers perceive that training 
for older workers is a poor investment, which yields benefits over too short a time (Eurofound, 2016[65]). However, it is essential for older workers to participate in training to re-skill and up-skill, if they are to extend their working lives as life expectancy keeps getting higher. In order to keep older workers in labour force longer, sufficient opportunities to participate in adult learning, incentives for later retirement (e.g. tax benefits) and desirable working conditions for older workers (e.g. flexible working hours and part-time work options) should be provided. In addition, it is essential to make older workers aware of the importance of continuous re- and up-skilling through adult learning opportunities. Social campaigns, mentoring and guidance services can play a significant role in changing their mind-sets (OECD, 2017[66]).

77. Evidence found in OECD countries suggests that, at the aggregate level, technological change does not penalise older workers more than prime-age workers. However, age-related differences in the use of digital technology can put older workers at a disadvantage. In addition, age-related differences in the use of digital technologies also reflect the fact that older people generally work in more heavily routinised occupations than the younger generation. It is of high importance to improve their access to non-routine jobs through life-long learning (OECD, 2017[66]).

78. Some policies have been put in place in Thailand to foster adult learning for older workers. For example, the Ministry of Labour set a target to provide 18-30 hour job training to 8160 elderly people between 2019-2020, through Offices for Skill Development and Skills Development Institutes situated across the country. More than 100 courses, ranging from traditional cookery to social media, are developed according to area-based needs and new technology to ensure a secure income, self-reliance and to address labour shortages in specific areas. In addition, over 1100 senior schools acts as a space for knowledge sharing and cultural events to promote well-being and personal development for elderly people (Ministry of Social Development and Human Security).

79. To overcome age-related barriers, it is of crucial importance that policy makers provide training that is more attractive in the eyes of older workers and persuade employers of the benefits of providing training to older workers. For example, training could be directly tied to a specific task or job to ensure that positive returns of training follow swiftly, benefitting both employers and employees at the end of their careers (OECD, 2017[66]).

80. On the other hand, evidence suggests that women may face higher barriers to participate in training, even though women are predominantly employed in the jobs that are more likely to be affected by automation, and therefore, sufficient re-skilling and up-skilling opportunities are essential (ILO, 2019 [67]; OECD, 2019[68]). Traditional social norms and gender stereotypes put heavier burdens of unpaid care work on women, while leaving little time for them to participate in training. In addition, employers tend to underinvest in workers who are perceived to have a weaker attachment to the company, such as contract workers or women who may take up caring responsibilities (OECD, 2019 $\left.{ }_{[68]}\right)$. Moreover, a large share of women work in informal sectors, where access to training is difficult.

81. In order to ensure women are included in adult learning, the Ministry of Labour of Thailand has developed a new STEM training program for women workers in the electronics sector. The Department of Skills Development (DSD) and the ILO worked together on a STEM related skills development programme for women workers. In the context of the Thailand 4.0 development plan, the programme aims to invest in women's capabilities and enhance their access to decent and productive employment. It is also in line with the objectives of the Decent Work Country Programme signed by the Ministry of Labour, employers and workers organisations early 2019. So far, 1050 women workers at Seagate Technology plant in Korat, Sung Noen District, Nakhon Ratchasima province, completed the training programme (ILO, 2019[67]).

82. Several OECD countries provide training particularly targeting women. For example, in Ireland, Women ReBOOT, an enterprise-led initiative co-funded and supported by Skillnet Ireland, supports inactive women in developing skills and self-confidence to re-enter the technology sector after a career break. The programme includes group seminars, technology and knowledge training, individual coaching 
and in-company work placements. In Canada, unions play an active role in setting up specific training programmes for women in sectors where they are underrepresented (OECD, 2019[68]).

83. Finally, lack of motivation is one important barrier faced by adults, and evidence suggests that adults, in particular those with low skills, are unable to recognise the need to develop their skills further (Windisch, 2015[69]). Hence, the engagement of adults in learning activities should go beyond providing opportunities to those who ask for them. Providing high-quality information and individualised advice and guidance services, raising awareness on the benefits of learning, for example through awareness campaigns, ensuring that wages more closely reflect productivity gains resulting from training participation are some of the ways policy can encourage higher and more inclusive participation (OECD, 2019[68]; OECD, 2019[6]).

\section{Strengthening adult learning investment and incentives toward in-demand skills}

84. It is difficult but important to ensure adult learning is aligned with labour market needs in a rapidly changing world. To effectively support workers and job seekers, adult learning programmes need to be designed to reflect current as well as future labour market needs, and incentives for participants and providers need to be set to guide the choice of courses towards skills in demand. It is crucial that policy makers, individuals and employers have a good understanding of these changing skill needs, so that they can make informed decisions on updating occupational standards, designing or revising training policies and programmes, setting appropriate incentives and providing advice to people on skill development (OECD, 2016[70]).

85. As discussed above, countries differ widely in terms of methods used to identify their skill needs, but also the extents at which these exercises are conducted, and how skills information is shared and used to inform policy-making. Thailand carries out skills assessment and anticipation, but not on a regular basis. Therefore, skills information is available but somewhat limited. The National Statistical Office, Ministry of Labour, and Office of National Higher Education Science Research and Innovation Policy Council, among others, provide information on current and future skills demand as well as skills shortages based on survey data and interviews with firms. This represents a useful source of information for the Office for Standard Development and Labour under the Ministry of Labour to develop national skill standard, standardised tests and skills requirements for new rising industries, such as next-generation automotive, intelligent electronics, robotics, and aviation.

86. However, evidence shows that the output from skills assessment and anticipation (SAA) exercises is not always fully exploited. Across European OECD countries, only $13 \%$ of firms have a complete overlap between the skills they identify as priority for the development of the firm and the skills they are training their workers in (OECD, 2019 $\left.{ }_{[59]}\right)$. According to Skills Development Survey (2019) from National Statistical Office of Thailand, in 2019 the largest number of adult training courses were provided in agriculture, followed by management, home economics and computers. While training in these areas can certainly be important, it does not necessarily correspond with the areas that are in need of training the most according to SAA exercises. Thai employers could greatly benefit from a more thorough analysis of their skills and training needs and corresponding provision of training.

87. In some OECD countries, results from SAA exercises are used to determine which training programmes to deliver. In France, for example, the public employment service (PES) uses the information from an employer survey on recruitment activities and needs to decide on the amount and type of training courses to purchase from training providers (OECD, 2017[71]). In Portugal, regional branches of the PES analyse the skill needs in their region, including information on vacancies from the local PES offices, to determine the offer of vocational training within the network of Employment and Vocational Training Centres. In Denmark, sector-specific continuing training and education committees use skill needs 
information to determine which training programmes to offer in adult vocational training centres (OECD, 2019[68]).

88. One particular area in which many countries are actively developing adult learning programmes is digital skills. Digital skills have become increasingly important in recent years, and research suggests that their importance will continue to grow over the years, especially since the COVID-19 crisis. During the pandemic, teleworking and the use of online tools, such as video conferences, mobile banking and online courses, have increased significantly in numerous sectors around the world to maintain distancing and avoid personal contacts to the extent possible. This new way of working is likely to continue in many sectors of the economy even in the post-COVID world, reinforcing the importance of and demand for digital skills (OECD, 2020[57]). However, even though many countries now consider digital skills to be a foundation skill, along with literacy and numeracy, several countries are experiencing digital skill shortages (OECD, 2017 $[48]$ ). In Thailand, several training programmes with a particular focus on new technology and hightech skills are in place. For example, the Ministry of Labour's programme, Skills Development for Technological Changes in Manufacturing and Service Sector (โครงการพัฒนาฝีมือแรงงานเพื่อรองรับการเปลี่ยนแปลงเทคโนโลยีของภาคอุตสาหกรรมและบริการ), aims to provide training to 5200 new workers with no or limited skills with particular focus on technology and foreign language in support of targeted industries. Another example is Increasing Workforce Potential for Thailand 4.0 (โครงการเพิ่มศักยภาพแรงงานรองรับ Thailand 4.0), a programme which aims to provide 30-hour training to more than 14100 workers in potentially fast-growing industries, SMEs and the unemployed, focusing on five core technologies according to the Thailand 4.0 policy. ('Skills Development Guideline for Fiscal Year 2019' by the Department of Skill Development, Ministry of Labour)

89. Another way that adults can be guided in their choice of training options is by targeting certain financial or nonfinancial incentives to training programmes that address skill needs in the labour market. The availability of financial incentives for individuals, such as vouchers or grants, can be limited to certain training programmes. Similarly, employers can receive financial support, such as subsidies or tax exemptions, when training their workers for certain in demand skills (OECD, 2017[72]). In Austria, for example, a grant scheme (Fachkräftestipendium) is available for individuals participating in training related to PES-identified shortage occupations. This grant provides income support during the training participation, under the condition that the training programme lasts for at least three months and covers at least 20 training hours per week (OECD, 2019[68]).

90. A softer way of steering individuals and employers towards the development of skills that are in high demand in the labour market is through information and guidance. As one of the goals of career guidance services is to help job-seekers' transition into sustainable employment, information on labour market needs is generally taken into account when providing these services.

91. Incentives to encourage training particularly on in-demand skills are not in place in Thailand, yet. However, efforts are being made to provide high-quality career guidance. The Ministry of Labour in Thailand has established in 2015 'Smart Job Center', a platform to provide complete employment services including advice and guidance for career development. OECD (2019) shares good practices and examples of career guidance websites which provide information about skill needs. For example, the Canadian Job Bank web portal allows users to consult registered vacancies, and obtain information about the employment prospects of specific occupations in specific regions. The New Zealand Occupation Outlook provides extensive information on labour supply and demand in over 100 occupations (OECD, 2019[68]).

\section{Assisting workers in sectors undergoing structural change}

92. Adult learning must respond to changing skill demands by specifically targeting those adults who are specialised in skills that have become or are likely to become obsolete. For example, workers in jobs at high risk of automation may need to retrain to learn how to handle the introduction of new technologies, 
or to find a less automatable job either within the same sector/occupation or in a different one (OECD, $\left.2019_{[68]}\right)$.

93. There is currently no policy in place in Thailand to assist workers in sectors undergoing structural change. However, Thailand has recently set up strategic policy approach to support these workers. Several government agencies, including the Ministry of Labour and the newly-established Ministry of Higher Education, Science, Research and Innovation, have recently announced plans committed to supporting re-skilling and lifelong learning particularly for working age population who potentially face career and occupational change.

94. Some OECD countries already have programmes in place to re-train workers in firms facing major technological disruption. In Austria, Outplacement Labour Foundation (Arbeitsstiftung) programmes were introduced by social partners to support workers in the case of structural changes through appropriate labour market policies. These Foundations can be formed by one or multiple employers, but also at the sector and regional level when specific regions or sectors are affected by major staff cuts. The programmes are co-financed by local labour market actors, including the PES and the affected employers. Funding is available to cover training costs, allowances for course related additional costs, and active job-search assistance and career guidance costs (OECD, 2019[68]).

95. However, evidence suggests that, in general, relatively few countries have adult learning initiatives in place that directly target workers in jobs that have a high risk of undergoing significant change (OECD, $\left.2019_{[6]}\right)$. Preparing these individuals for the changes that are likely to happen in the near future is crucial to facilitate their transition into new tasks, jobs or forms of work. Strong basic and transversal skills are essential for people to respond to changing skill needs, and many countries have policies in place to develop these skills. However, further efforts could be made to make these programmes more widely available and promote them among the most vulnerable workers. Strong SAA information is imperative for these individuals to make informed training choices and for governments to design effective policies that help them up-skill or re-skill for the jobs of the future (OECD, 2019 $\left.9_{[68]}\right)$. 


\section{Table 1. Recommendations to get the right skills for future prosperity}

\begin{tabular}{l|l}
\hline \multicolumn{1}{c}{ Findings (main findings in bold) } & \multicolumn{1}{c}{ Recommendations (key recommendations in bold) } \\
\hline \multicolumn{1}{c}{ Assessing skill needs } \\
\hline \begin{tabular}{l|l} 
Skill needs in the Thai labour market are not assessed in a regular \\
and systematic way.
\end{tabular} & $\begin{array}{l}\text { Develop robust tools to regularly assess skill needs at the } \\
\text { national, regional and sectoral level. } \\
\text { Create a knowledge-sharing platform to bring together the different skill } \\
\text { needs assessment exercises carried out by different actors. }\end{array}$ \\
\hline \begin{tabular}{l|l} 
Student achievement is low by international standards and \\
regional inequalities are large.
\end{tabular} & $\begin{array}{l}\text { Continue expanding pre-primary education and ensure it reaches the } \\
\text { most vulnerable populations while investing in pre-primary teachers' } \\
\text { professional development. }\end{array}$ \\
& $\begin{array}{l}\text { Increase investment in teacher professional development, and re- } \\
\text { structure the incentives currently in place for teacher placement. } \\
\text { Consolidate the implementation of school curricula and improve } \\
\text { education infrastructure in rural areas. }\end{array}$ \\
\hline $\begin{array}{l}\text { Rapidly ageing population and a shrinking student population put } \\
\text { pressure on sustainability of Higher Education Institutions. }\end{array}$ & $\begin{array}{l}\text { Continue efforts to stimulate competition between HEls and strengthen } \\
\text { the alignment between their study offers and "Thailand 4.0" while } \\
\text { modernising teaching methods. }\end{array}$ \\
& $\begin{array}{l}\text { Support the provision of high-quality career guidance services at the } \\
\text { level of post-secondary and tertiary education. }\end{array}$ \\
\hline $\begin{array}{l}\text { Despite a slight decline in recent years, the wage benefit to } \\
\text { university degrees is strong. }\end{array}$ & $\begin{array}{l}\text { Continue efforts to increase educational attainment and support the } \\
\text { development of higher-level skills. }\end{array}$ \\
& $\begin{array}{l}\text { Pair skills policies with policies that stimulate the demand for high- } \\
\text { level skills in the labour market by lowering barriers to entry for } \\
\text { firms, intensifying efforts to boost technology adoption levels and } \\
\text { actively promoting entrepreneurship through professional and } \\
\text { educational channels. }\end{array}$ \\
\hline
\end{tabular}

Providing responsive and inclusive adult learning opportunities

Data collection and analysis on participation of adults in training and employers' provision of training are lacking.
Improve existing household and/or employer surveys or build new surveys focusing on the topic of adult learning to retrieve detailed information.

Sufficiently use labour market information to develop relevant policies and adult learning programmes.

Many adults, including older workers, low skilled workers and women, face high barriers to participate in training opportunities.

There is limited guidance to help individuals and employers make skills development investments that correspond to the needs of the labour market.

Workers going though structural changes do not have sufficient labour market information and access to necessary trainings.
Develop flexible training programmes for adults and provide incentives to facilitate access to training.

Tie guidance services closely to labour market information, and make training incentives more generous for programmes that develop indemand skills.

Promote targeted support (e.g. career guidance and trainings on skills in high demand) for workers in jobs with high risk of significant changes.

Provide them with training opportunities to gain strong basic and transversal skills to facilitate the smooth transition to new jobs or tasks. 


\section{References}

Acemoglu, D. and P. Restrepo (2017), Robots and Jobs: Evidence from US Labor Markets.

Asian Correspondent (2016), Thai universities in 'crisis' as student enrollments decline, https://asiancorrespondent.com/2016/06/thailand-university-crisis-student-enrollmentsdecline/.

Bangkok Post (2020), Robots to aid in disinfectant battle, https://www.bangkokpost.com/thailand/general/1900675/robots-to-aid-in-disinfectant-battle (accessed on 18 May 2020).

Bangkok Post (2019), Thai universities struggle to keep up, https://www.bangkokpost.com/thailand/general/1604990/thai-unis-struggle-to-keep-up (accessed on 18 May 2020).

Blomström, M. and A. Kokko (2001), FDI and Human Capital: A Research Agenda organised by the OECD Development Centre 2 FDI and Human Capital: A Research Agenda, http://www.oecd.org/dev/2699493.pdf.

Bloom, D. and D. Canning (2003), "Health as Human Capital and its Impact on Economic Performance", The Geneva Papers on Risk and Insurance 2, pp. 304-315.

Botev, J. et al. (2019), "A new macroeconomic measure of human capital with strong empirical links to productivity", OECD Economics Department Working Papers, No. 1575, OECD Publishing, Paris, https://dx.doi.org/10.1787/d12d7305-en.

Broad Institute (2018), Questions and Answers about CRISPR, https://www.broadinstitute.org/what-broad/areas-focus/project-spotlight/questions-andanswers-about-crispr.

Centre, U. (ed.) (2019), Education (dataset), http://data.uis.unesco.org/Index.aspx?DataSetCode=EDULIT DS\&popupcustomise=true\&lan $\mathrm{g}=\mathrm{en}$.

Chang, J. and P. Huynh (2016), "ASEAN in Transformation: The future of jobs at risk of automation", Bureau for Employers' Activities Working Paper, No. 9, ILO, Bangkok, https://www.ilo.org/wcmsp5/groups/public/---ed dialogue/--act emp/documents/publication/wcms 579554.pdf (accessed on 15 November 2018).

Crocco, O. (2018), "Thai Higher Education: Privatization and Massification", in Education in the Asia-Pacific Region, Springer Nature, http://dx.doi.org/10.1007/978-981-10-7857-6 9.

Deming, D. (2017), "The Growing Importance of Social Skills in the Labor Market", The Quarterly Journal of Economics, Vol. 132/4, pp. 1593-1640, http://dx.doi.org/10.1093/qje/qix022.

Eurofound (2016), First Findings: Sixth European Working Conditions Survey, Publications Office, Luxembourg.

Flabbi, L. and R. Gatti (2018), "A Primer on Human Capital", Policy Research Working Paper, No. 8309, World Bank, Washington, http://econ.worldbank.org. (accessed on 23 July 2020). 
GovTech SEA (2019), GovTech SEA, https://govtechsea.com/southeast-asia-in-the-pisa-2018report-preparing-for-the-future-through-education/ (accessed on 14 May 2020).

Heckman, J., L. Lochner and P. Todd (2006), "Earnings Functions, Rates Of Return And Treatment Effects: The Mincer Equation And Beyond", http://dx.doi.org/10.1016/S15740692(06)01007-5.

IECF Monitor (2017), Thailand's growing supply-demand gap in higher education, https://monitor.icef.com/2017/10/thailands-growing-supply-demand-gap-higher-education/ (accessed on 19 December 2019).

ILO (2020), COVID-19 and employment in the tourism sector: Impact and response in Asia and the Pacific, ILO Regional Office for Asia and the Pacific, https://www.unwto.org/unwtotourism- (accessed on 7 May 2020).

ILO (2019), "ILO and Thailand enhance women's access to technical skills in electronics industry", ILO, https://www.ilo.org/asia/media-centre/news/WCMS 721350/lang-en/index.htm\#: :text=Women\%20in\%20STEMILO\%20and\%20Thailand\%20enhance\%20women's\%20access\%20to\%20technical\%20skills \%20in, workers\%20in\%20the\%20electronics\%20sector.

ILO (2016), Non-standard Employment Around the World: Understanding Challenges, Shaping Prospects., ILO Publishing, Geneva.

IOM (2019), World migration Report 2020, International Organization for Migration, Geneva.

Kenan Foundation Asia (2020), 3 Consequences of COVID-19 on Thai Education, https://www.kenan-asia.org/covid-19-thai-education/ (accessed on 18 May 2020).

Kis, V. and H. Windisch (2018), "Making skills transparent: recognising vocational skills acquired through workbased learning", OECD Education Working Paper.

Lathapipat, D. (2017), Thailand-wanted:A quality education for all.

Mcmahon, W. (2000), The Impact of Human Capital on Non-Market Outcomes and Feedbacks on Economic Development.

Michael, R. (2018), Education in Thailand, https://wenr.wes.org/2018/02/education-in-thailand-2 (accessed on 19 December 2019).

Nedelkoska, L. and G. Quintini (2018), "Automation, skills use and training", OECD Social, Employment and Migration Working Papers, No. 202, OECD Publishing, Paris, https://dx.doi.org/10.1787/2e2f4eea-en.

NESDB (2017), The Twelfth National Economic and Social Development Plan (2017-2021).

OECD (2020), A systemic resilience approach to dealing with Covid-19 and future shocks, http://www.oecd.org/coronavirus/policy-responses/a-systemic-resilience-approach-to-dealingwith-covid-19-and-future-shocks-36a5bdfb/\#section-d1e154.

OECD (2020), COVID-19 and International Trade: Issues and actions, https://read.oecdilibrary.org/view/?ref=128 128542-3ijg8kfswh\&title=COVID-19-and-international-trade-issuesand-actions. 
OECD (2020), OECD Economic Surveys: Thailand 2020: Economic Assessment, OECD

Publishing, Paris, https://dx.doi.org/10.1787/ad2e50fa-en.

OECD (2020), Tackling coronavirus (COVID-19): Contributing to a global effort, Public employment services in the frontline for jobseekers, workersand employers, OECD, Paris Publishing, https://read.oecd-ilibrary.org/view/?ref=131 131935-ag47t7rrfi\&title=Publicemployment-services-in-the-frontline-for-jobseekers-workers-and-employers.

OECD (2019), Country Note: Programme for International Student Assessment (PISA) Results from 2018.

OECD (2019), Getting Skills Right Creating responsive adult learning systems, OECD, http://www.oecd.org/employment/emp/.

OECD (2019), Getting Skills Right: Creating Responsive Adult Learning Systems, OECD, http://www.oecd.org/els/emp/adult-learning-systems-2019.pdf (accessed on 17 September 2019).

OECD (2019), Getting Skills Right: Future-Ready Adult Learning Systems, Getting Skills Right, OECD Publishing, Paris, https://dx.doi.org/10.1787/9789264311756-en.

OECD (2019), "Individual Learning Accounts: Design is key for success", https://www.oecdilibrary.org/employment/oecd-employment-outlook-2019 59d17791-en.

OECD (2019), OECD Economic Surveys: Malaysia 2019, OECD Publishing, Paris, https://dx.doi.org/10.1787/eaaa4190-en.

OECD (2019), OECD Employment Outlook 2019: The Future of Work, OECD Publishing, Paris, https://dx.doi.org/10.1787/9ee00155-en.

OECD (2019), OECD Investment Policy Review of Southeast Asia, OECD Publishing, Paris, http://www.oecd.org/investment/oecd-investment-policy-review-southeast-asia.htm (accessed on 15 January 2019).

OECD (2019), OECD Skills Strategy 2019: Skills to shape a better future, OECD Publishing, Paris.

OECD (2019), PISA 2018 Results (Volume I): What Students Know and Can Do, PISA, OECD Publishing, Paris, https://dx.doi.org/10.1787/5f07c754-en.

OECD (2019), PISA 2018 Results (Volume II): Where All Students Can Succeed, PISA, OECD Publishing, Paris, https://dx.doi.org/10.1787/b5fd1b8f-en.

OECD (2018), Multi-dimensional Review of Thailand (Volume 1): Initial Assessment, OECD Development Pathways, OECD Publishing, Paris, https://dx.doi.org/10.1787/9789264293311en.

OECD (2018), The Productivity-Inclusiveness Nexus, OECD Publishing, Paris, https://dx.doi.org/10.1787/9789264292932-en.

OECD (2017), Financial incentives for steering education and training., OECD, Paris, https://www.oecd-ilibrary.org/docserver/9789264272415en.pdf?expires $=1575298669 \& i d=i d \& a c c n a m e=0 c i d 84004878 \&$ checksum $=17$ C93298E14D07 8FA34027D03F9484AE. 
OECD (2017), Getting Skills Right: France, Getting Skills Right, OECD Publishing, Paris, https://dx.doi.org/10.1787/9789264284456-en.

OECD (2017), Getting Skills Right: Skills for Jobs Indicators, Getting Skills Right, OECD Publishing, Paris, https://dx.doi.org/10.1787/9789264277878-en.

OECD (2017), Getting Skills Right: Skills for Jobs Indicators, OECD Publishing, http://dx.doi.org/10.1787/9789264277878-en.

OECD (2017), International Migration Outlook 2017, OECD Publishing, Paris, https://dx.doi.org/10.1787/migr outlook-2017-en.

OECD (2017), Preventing Ageing Unequally, OECD Publishing, Paris, https://read.oecdilibrary.org/employment/preventing-ageing-unequally 9789264279087-en\#page3.

OECD (2016), Getting Skills Right: Assessing and Anticipating Changing Skill Needs, Getting Skills Right, OECD Publishing, Paris, https://dx.doi.org/10.1787/9789264252073-en.

OECD (2016), "The NEET challenge: What can be done for jobless and disengaged youth?", in Society at a Glance 2016: OECD Social Indicators, OECD Publishing, Paris, https://dx.doi.org/10.1787/soc glance-2016-4-en.

OECD (2013), PISA 2012 Results: Excellence through Equity (Volume II): Giving Every Student the Chance to Succeed, PISA, OECD Publishing, Paris, https://dx.doi.org/10.1787/9789264201132-en.

OECD (2013), Southeast Asian Economic Outlook 2013: With Perspectives on China and India, OECD Publishing, Paris, https://dx.doi.org/10.1787/saeo-2013-en.

OECD/UNESCO (2016), Education in Thailand: An OECD-UNESCO Perspective, Reviews of National Policies for Education, OECD Publishing, Paris, https://dx.doi.org/10.1787/9789264259119-en.

Pattaya Mail (2020), Thai specialists from Mahidol University introduce cheaper, faster COVID19 tests - Pattaya Mail, https://www.pattayamail.com/coronavirus/thai-specialists-frommahidol-university-introduce-cheaper-faster-covid-19-tests-297082 (accessed on 18 May 2020).

Paweenawat, S. and J. Vechbanyongratana (2015), "Wage Consequences of Rapid Tertiary Education Expansion in a Developing Economy: The Case of Thailand", The Developing Economies, Vol. 53/3, pp. 218-231, http://dx.doi.org/10.1111/deve.12078.

PISA (2015), PISA 2015 Results in Focus, Angel Gurría.

Richard Desjardins (ed.) (2017), Political Economy of Adult Learning Systems, Bloomsbury Academic, London, New York.

Rincon Aznar, A. et al. (2015), UK skills and productivity in an international context, The National Institute of Economic and Social Research, http://file:///C:/Users/Espinoza R/Downloads/BIS15-704-UK-skills-and-productivity-in-an-international context.pdf (accessed on 6 January 2019). 
Sanders, R. (2016), "Genetic switch could be key to increased health and lifespan", http://news.berkeley.edu/2016/05/03/genetic-switch-could-be-key-to-increased-healthandlifespan.

Shah, C. and G. Burke (2005), "Skills Shortages: Concepts, Measurement and Policy Responses", Australian bulletin of labour, Vol. 31/1, https://dspace.flinders.edu.au/xmlui/handle/2328/27700 (accessed on 2 April 2019).

Srithanpong, T. (2014), "Productivity and wage spillovers from FDI in Thailand: Evidence from plant-level analysis", 29, No. 2, Thailand Development Research Institute.

Tangtipongkul, K. (2015), "Rates of Return to Schooling in Thailand", Asian Development Review, Vol. 32/2, pp. 38-64, http://dx.doi.org/10.1162/ADEV a 00051.

Teerawichitchainan, B. et al. (2019), Thailand's Older Persons and Their Well-being An Update based on the 2017 Survey of Older Persons in Thailand, HelpAge International.

The Equitable Education Fund (2020), What We Do, https://www.eef.or.th/en/eef/\#about-en (accessed on 18 June 2020).

UNESCO Institute for Lifelong Learning (2016), Third Global Report on Adult Learning and Education - The Impact of Adult Learning and Education on Health and Well-Being; Employment and the Labour Market; and Social, Civic and Community Life, UNESCO Institute for Lifelong Learning, Hamburg, http://www.unesco.org/ (accessed on 19 November 2018).

UNESCOIOECD (2016), Education in Thailand: An OECD-UNESCO perspective, Reviews of National Policies for Education.

University of the Thai Chamber of Commerce (2020), Thailand's economic forecast for the year 2020, Economic and Business Forecasting Center, http://cebf.utcc.ac.th/upload/report file/file th 112d16y2020.pdf (accessed on 14 May 2020).

Windisch, H. (2015), "Adults with low literacy and numeracy skills: A literature review on policy intervention", OECD Education Working Papers, No. 123, OECD Publishing, Paris, https://dx.doi.org/10.1787/5jirxnjdd3r5k-en.

World Bank (2016), World Development Report 2016: Digital Dividends, https://www.worldbank.org/en/publication/wdr2016 (accessed on 21 January 2020).

เสาวณี จันทะพงษ์ and นางสาวกานต์ชนิต เลิศเพียรธรรม (Chantapong, Saovanee and Kanchanit Lertpienthum) (2018), "กับดัก Skills Mismatch และความท้าทายสู Education 4.0", MPG Economic Review, Bank of Thailand (in Thai). 